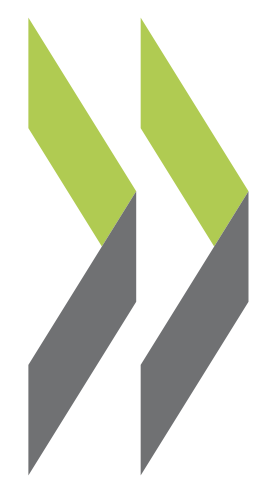

OECD Economics Department Working Papers No. 1674

The impact of COVID-19 on corporate fragility in the United Kingdom: Insights from a new calibrated firm-level Corporate Sector AgentBased (CAB) Model

Sebastian Barnes, Robert Hillman, George Wharf, Duncan MacDonald 
ECONOMICS DEPARTMENT

THE IMPACT OF COVID-19 ON CORPORATE FRAGILITY IN THE UNITED KINGDOM: INSIGHTS FROM A NEW CALIBRATED FIRM-LEVEL CORPORATE SECTOR AGENTBASED (CAB) MODEL

\section{ECONOMICS DEPARTMENT WORKING PAPERS No. 1674}

Sebastian Barnes, Robert Hillman, George Wharf and Duncan MacDonald

OECD Working Papers should not be reported as representing the official views of the OECD or of its member countries. The opinions expressed and arguments employed are those of the author(s).

Authorised for publication by Alain de Serres, Deputy Director, Policy Studies Branch, Economics Department.

This work has been supported by the OECD NAEC Innovation LAB.

All Economics Department Working Papers are available at www.oecd.org/eco/workingpapers 
OECD Working Papers should not be reported as representing the official views of the OECD or of its member countries. The opinions expressed and arguments employed are those of the author(s).

Working Papers describe preliminary results or research in progress by the author(s) and are published to stimulate discussion on a broad range of issues on which the OECD works.

Comments on Working Papers are welcomed, and may be sent to OECD Economics Department, 2 rue André Pascal, 75775 Paris Cedex 16, France, or by e-mail to eco.contact@oecd.org.

All Economics Department Working Papers are available at www.oecd.org/eco/workingpapers.

This document and any map included herein are without prejudice to the status of or sovereignty over any territory, to the delimitation of international frontiers and boundaries and to the name of any territory, city or area.

The statistical data for Israel are supplied by and under the responsibility of the relevant Israeli authorities. The use of such data by the OECD is without prejudice to the status of the Golan Heights, East Jerusalem and Israeli settlements in the West Bank under the terms of international law.

\section{๑) OECD (2021)}

You can copy, download or print OECD content for your own use, and you can include excerpts from OECD publications, databases and multimedia products in your own documents, presentations, blogs, websites and teaching materials, provided that suitable acknowledgment of OECD as source and copyright owner is given. Requests for commercial use and translation rights should be submitted to PubRights@oecd.org 


\section{Abstract/Résumé \\ The impact of Covid-19 on Corporate Fragility in the United Kingdom: Insights from a new calibrated firm-level Corporate Sector Agent-Based (CAB) Model}

Covid-19 and the associated restrictions on interaction have led to an unprecedented shock to activity and firms' balance sheets. To assess the impact, this paper applies a new large-scale firm-level simulation model calibrated to the United Kingdom (UK). The paper specifically examines the Coronavirus Job Retention Scheme (CJRS) furlough program and a credit guarantee.

The Corporate Sector Agent-Based (CAB) Model (Hillman, Barnes, Wharf and MacDonald, 2021) takes into account: heterogeneity across firms; interactions between firms across a realistic customer-supplier network; and rule-of-thumb behaviour by firms and bankruptcy constraints. The model amplifies the effect of shocks and generates substantial persistence and overshooting, as well as displaying a number of nonlinearities. The CAB uses a data-rich approach based on ORBIS firm-level data and the OECD InputOutput tables. Simulations in this paper are calibrated to the observed path of UK output in 2020.

The analysis generates a number of insights on the impact of Covid-19 on corporate fragility. First, in the absence of any policy response, the Covid-19 shock leads to a peak fall in output of $21 \%$, larger than the exogenous final demand shock. Over $15 \%$ of firms fail in the first two years with output remaining $5 p p$ lower than in a no-Covid scenario even as exogenous final demand recovers. Firms that fail are more likely to be SMEs and in highly-exposed sectors with almost a quarter of firms failing in the Accommodation and Food sector. The reasons for individual firm failure are multi-factored.

Second, the massive policy response has been highly effective in supporting output and avoiding firm failure due to Covid-19. As well as supporting output during the shock, the policy support allows activity to recover to just $2 \%$ below the no-Covid scenario after two years.

As has been observed in the bankruptcy statistics to date (Insolvency Service, 2021), the rate of firm failures has been lower recently compared to normal times. This counterintuitive outcome reflects in part that policy support helps weaker firms that would have failed in normal times, as well as protecting previously profitable firms that would have failed as result of the Covid-19 shock. The nature of the Covid19 shock further contained the impact as many were only modestly affected and the shock was sufficiently short that, with many firms having cash reserves to cover at least 3 months' sales, firms could survive. A longer or deeper shock could have had a markedly worse impact. A large share of output is accounted for by larger firms that tend to be financially stronger and have more diversified and robust customer and supplier networks.

The government's support measures benefit firms with below-average productivity that would have likely failed in normal times: these "zombie firms" could drag on aggregate productivity in the years ahead, though the effect of policy is more a delay than an avoidance of eventual failure. In addition, firms whose business models have been permanently disrupted by Covid-19 could yet survive for some time, if they were in good financial shape prior to the crisis and accessed policy supports.

Third, in terms of policy design, targeting supports only to previously profitable firms or those in severely affected sectors would have reduced the extent to which weaker firms were supported, but at the cost of lowering incomes for workers and slowing the recovery. Additionally a number firms that would have survived in normal times, even if their accounts show they were unprofitable in the previous year, would have been pushed into failure without access to borrowing and the furlough. Given these challenges with targeting, the use of broad supports during the Covid-19 crisis appears justified. The availability of credit appears to play a more powerful role than the CJRS job replacement scheme in avoiding firm failures. Withdrawing support in mid-2021 would lead to a sharp rise in failures, but average failures over 2020 and 2021 would remain at rates similar to normal times. 
Keywords: firm dynamics, Covid-19, input-output analysis, agent-based modelling, network analysis, firmlevel data, bankruptcy, short-time working schemes, credit guarantees, financial stability

JEL codes: D21, D22, D57, D85, D85, E27, G33

$* * * * *$

\section{L'impact du COVID-19 sur la fragilité des entreprises au Royaume-Uni : ce que nous en dit un nouveau modèle microéconomique multi-agents (CAB, Corporate Sector Agend-Based Model)}

Le COVID-19 a abouti à un choc sans précédent sur l'activité et le bilan des entreprises. Pour évaluer cet impact, ce document applique un nouveau modèle de simulation microéconomique à grande échelle, calibré à partir des données du Royaume-Uni. Il examine plus spécialement le dispositif de chômage partiel mis en place dans le cadre de la pandémie (Coronavirus Job Retention Scheme, CJRS) et un mécanisme de garantie de prêts.

Le modèle microéconomique multi-agents (CAB, Corporate Sector Agend-Based Model) (Hillman, Barnes, Wharf et MacDonald, 2021) prend en compte divers facteurs : l'hétérogénéité d'une entreprise à l'autre ; les interactions entre les entreprises au sein d'un réseau complet de clients-fournisseurs et les comportements empiriques en fonction des entreprises et des contraintes de faillite. Le modèle amplifie les effets des chocs et génère d'importants effets persistants et plus profonds, tout en affichant un certain nombre de non-linéarités. Cette modélisation fait appel à de très nombreuses données issues de la base ORBIS, qui recueille des données au niveau des entreprises, et des tableaux d'entrées-sorties de l'OCDE. Les simulations effectuées dans ce document sont calibrées à partir de l'évolution de la production au Royaume-Uni en 2020.

L'analyse livre un certain nombre d'éclairages sur l'impact du COVID-19 sur la fragilité des entreprises. Tout d'abord, en l'absence de riposte des pouvoirs publics, le choc du COVID-19 aboutit à une perte de production culminant à $21 \%$, soit un taux supérieur au choc sur la demande finale exogène. Plus de $15 \%$ des entreprises font faillite au cours des deux premières années, la production demeurant inférieure de 5 points de pourcentage à celle du scénario hors COVID-19, même avec le redressement de la demande finale exogène. Les entreprises qui font faillite sont plus susceptibles d'être des PME et d'opérer dans des secteurs fortement exposés, quasiment un quart de ces entreprises en faillite relevant du secteur de l'hébergement et de la restauration. Les raisons présidant à la faillite de chaque entreprise tiennent à de multiples facteurs.

Ensuite, la riposte massive des pouvoirs publics a été très efficace pour soutenir la production et éviter les faillites liées à la pandémie. Outre qu'elles viennent à l'appui de la production durant le choc, les mesures de soutien des pouvoirs publics permettent à l'activité de se redresser à un niveau inférieur d'à peine $2 \%$ au niveau du scénario hors COVID-19 au bout de deux ans.

Ainsi qu'il ressort des statistiques de faillite (Insolvency Service, 2021), le taux de défaillance des entreprises mesuré récemment est inférieur à celui observé en temps normal. Ce résultat plutôt contreintuitif s'explique en partie par le fait que les mesures de soutien aident des entreprises plus fragiles qui auraient fait faillite en temps normal, et protègent celles qui, rentables avant la crise, auraient fait faillite à cause du choc du COVID-19. La nature de ce choc a, en outre, permis d'en contenir l'impact, car nombre d'entreprises n'ont été que modérément touchées et le choc a été de durée suffisamment courte pour qu'elles puissent survivre, de nombreuses entreprises disposant de réserves de trésorerie leur permettant de couvrir au moins trois mois de chiffre d'affaires. Un choc plus durable ou plus profond aurait pu avoir un impact nettement plus rude. Une part importante de la production est imputable aux grandes entreprises, qui sont généralement plus solides financièrement et disposent de réseaux de clients et de fournisseurs plus diversifiés et plus denses.

Les mesures de soutien des pouvoirs publics profitent aux entreprises affichant une productivité inférieure à la moyenne et qui auraient sans doute fait faillite en temps normal : ces "entreprises zombies" pourraient obérer la productivité agrégée dans les années à venir, même si les mesures prises ont plus 
pour effet de retarder la faillite que de l'éviter in fine. En outre, les entreprises dont le modèle économique a été durablement perturbé par la pandémie pourraient néanmoins survivre un certain temps si leur situation financière était correcte avant la crise et si elles ont pu bénéficier d'aides.

Troisièmement, s'agissant de la conception des mesures prises, cibler les aides sur les seules entreprises auparavant rentables ou sur celles des secteurs durement touchés aurait certes réduit l'ampleur du soutien aux entreprises plus fragiles, mais au prix d'une baisse des revenus des actifs et d'un ralentissement de la reprise. En outre, un certain nombre d'entreprises qui auraient survécu en temps normal, même si leurs comptes montraient qu'elles n'étaient pas rentables au cours de l'exercice précédent, auraient été poussées à la faillite si elles n'avaient pas eu accès à l'emprunt et au dispositif de chômage partiel. Étant donné les questions que soulève la sélectivité des aides, l'application de mesures généralisées pendant la crise du COVID-19 paraît justifiée. II semble que l'offre de crédit soit un levier plus puissant que le dispositif de chômage partiel mis en place dans le cadre de la pandémie (CJRS) pour éviter les faillites d'entreprises. La levée des aides à la mi-2021 conduirait à une nette augmentation des défaillances d'entreprises, mais leurs taux moyens en 2020 et 2021 resteraient comparables aux niveaux mesurés en temps normal.

Mots-clés : COVID-19, modélisation multi-agents, données microéconomiques, faillite, aides à l'activité économique, dispositifs de maintien dans l'emploi, garanties de prêts, modèles de trésorerie

Codes JEL : D21, D22, D57, D85, D85, E27, G33 


\section{Table of contents}

\section{The impact of Covid-19 on Corporate Fragility in the United Kingdom: Insights from a} new calibrated firm-level Corporate Agent-Based (CAB) Mode

2. Background - the Corporate Sector Agent-Based (CAB) Model 10

An agent-based model of the corporate sector 10

Modelling the Covid-19 shock 13

3. Insights on the impact of Covid-19 16

What would have happened in the absence of policy 16

The government's policy support has been highly effective 21

$\begin{array}{ll}\text { Designing policy to support firms } & 27\end{array}$

Conclusion $\quad 30$

Bibliography 31

\section{Tables}

Table 1. Firm failures are lower as policy supports have protected firms hard hit by Covid-19 and also supported firms that were already vulnerable

Table 2. Proportion of firms in each sector failing by end 2021 in different scenarios 26

Table 3. Median leverage of firms that borrow and survive during Covid-19 with policy 26

Table 4. Firm failures under alternative policy assumptions 28

Table 5. Loss of output (GVA) at end of 2021 under alternative policy assumptions 28

Table 6. The impact of support on firm survival by sector and initial financial health 29

Table 7. Experiment: The impact of stopping policy support in March 2021

\section{Figures}

Figure 1. Examples of UK customer-supplier network structures in the CAB model 11

Figure 2. Firm size and financial strength vary widely and is skewed 12

Figure 3. Sector exogenous final demand shocks used in the simulations $\quad 13$

Figure 4. Without policy, Covid-19 would have led to a very severe and lasting falling in output 17

Figure 5. Failures would have increased by a half with up to a quarter of firms failing in some sectors 18

Figure 6. Example of a viable firm that makes use of both policies in the Covid shock 19

Figure 7. More firms would have failed in sectors facing bigger demand shocks 20

Figure 8. Firms with lower productivity are more likely to have failed 21

Figure 9. With massive policy support, the depth and persistence of the Covid-19 loss of output has been reduced

Figure 10. Firm failures have been reduced by policy support 23

Figure 11. UK insolvencies have fallen so far during the pandemic $\quad 24$

\section{Boxes}

Box 1. The Coronavirus Job Retention Scheme and other Covid-19 Policy Interventions 
ECO/WKP(2021)25 | 7 


\title{
The impact of Covid-19 on Corporate Fragility in the United Kingdom: Insights from a new calibrated firm-level Corporate Agent-Based (CAB) Model
}

\author{
By Sebastian Barnes, Robert Hillman, George Wharf and Duncan MacDonald ${ }^{1}$
}

Covid-19 and associated restrictions on interactions have led to an unprecedented shock to activity and firms' balance sheets. Starting in March 2020, firms faced three waves of restrictions that for many weeks limited their ability to open to customers and allow workers on-site. Health restrictions and fear of the virus shifted demand away from activities requiring face-to-face interactions, such as restaurants and personal services, while the move to widespread teleworking reduced travel and activity in city-centre hubs.

To assess the impact, this paper applies a new large-scale firm-level agent-based simulation model, calibrated to the United Kingdom and focussing on the impact of policies that represent the Coronavirus Job Retention Scheme (CJRS) furlough program and a credit guarantee loan schemes such as the Coronavirus Business Interruption Loan Scheme.

Complexity theory suggests that, faced with a large shock such as Covid-19, the behaviour and interactions of the large number of heterogeneous firms in the economy could generate emergent properties at the aggregate level that have no simple relationship to individual behaviours (OECD, 2017). Agent-based models are well suited to understanding these effects and are beginning to be applied through large-scale calibrations to a range of economic policy problems (Chan-Lau, 2017[1]; Baptista et al., 2016 ${ }_{[2]}$ ).

The Corporate Sector Agent-Based (CAB) Model (Hillman, Barnes, Wharf and MacDonald, 2021) is built to explore the effects of the heterogeneity of firms; interactions between firms across a realistic customersupplier network; and rule-of-thumb behaviour by firms and bankruptcy constraints. The model shows that the dynamics of firm behaviour and interactions display a number of non-linearities. They amplify the effect of shocks and generate substantial persistence and overshooting. The model uses a data-rich approach based on ORBIS firm-level data and the OECD Input-Output tables (see Pinto Ribeiro, 2010, and Baigar et al 2020). The simulations in this paper are calibrated to the observed path of UK output since early 2020 until January 2021, followed by as assumption that overall final demand recovers to December 2019 levels by the end of 2021 .

\footnotetext{
1 The authors would like to thank Alain de Serres, Frank van Tongeren, Noemie Lisack, Lilas Demmou, Annabelle Mourourgane, Jon Pareliussen and seminar participants at the OECD, Banque de France, Econophysix Lab at the Ecole Polytechnique, ABM4Policy Network and the Department for Business, Energy \& Industrial Strategy for valuable comments and insights; Guido Franco and Peter Gal for useful advice on the ORBIS dataset; Stephen Powell and Greg Connell for useful insights on insolvency practice in the UK; and Michele Ortiz for preparing the paper. Any remaining errors remain our own. This work has been supported by the OECD NAEC Innovation LAB.
} 
The Covid-19 shocks to final demand lead firms to scale back their output, intermediate purchases and employment, amplifying the initial shock as the impact ripples through the supply chain. When demand recovers, output is restrained as firms only gradually adjust their expectations and orders and due to supply constraints. Firm failure would lead some workers to lose their jobs, but the permanent loss of output is mitigated by the ability of surviving firms to scale up production.

The model generates a number of insights on the impact of Covid-19 on output, firm failures, recovery and the role of policy:

- In the absence of any policy response, the Covid-19 shock would have led to a peak fall in gross output of $21 \%$ of output, $3 \mathrm{pp}$. larger than the exogenous final demand shock. Over $15 \%$ of firms would have failed in the first two years with output $5 \mathrm{pp}$. lower after two years than in a no-Covid scenario even as final demand recovers. Firms that fail are more likely to be Small- and Mediumsized Enterprises (SMEs) and in sectors with the largest demand shocks with as many as a quarter of firms failing in the Food and Accommodation sector.

- The government's policy response has been highly effective in supporting output and avoiding firm failure due to Covid-19. As well as supporting output during the shock, the model suggests that policy measures allow activity to recover to just $2 \%$ below the no-Covid scenario after two years.

- As has been observed in the bankruptcy statistics to spring 2021, the rate of firm failures is lower than in normal times. This counterintuitive outcome reflects in part that policy support helps weaker firms that would have failed in normal times, while protecting many firms that would have failed only as result of the Covid-19 shock. The nature of the Covid-19 shock further contained the impact as many sectors of the economy were not deeply affected and the shock was sufficiently short that, with many firms having cash reserves of at least 3 months' sales, firms could survive. A longer or deeper shock could have had a markedly worse impact. A large share of output is accounted for by larger firms that tend to be more financially robust and have more diversified and robust customer and supplier networks.

- The government support tend to benefit firms with below-average productivity that would have likely failed in normal times: these "zombie firms" could drag on aggregate productivity in the years ahead. In addition, firms whose business models have been permanently disrupted by Covid-19 could survive for a long time if there were financially in good shape prior to the crisis and accessed policy supports.

- In terms of policy design, targeting supports only to previously profitable firms or those in severely affected sectors would have reduced the extent to which firms that would have failed in normal times were supported, but at the cost of not supporting some firms whose failure was caused by the Covid-19 shock and with negative externalities for other firms. The availability of credit appears to play a more powerful role than the CJRS in avoiding firm failures. Withdrawing support too early could have adverse consequences, particularly limiting the access to borrowing.

This paper contributes to the literature on the economic impacts of Covid-19 in four areas. First, a number of exercises have examined the impact on cash flow on firms using firm-level data (OECD, 2020a; Bank of England, 2020). These "stress tests" captures the impact of the shock and firm heterogeneity, but ignore interactions between firms and the ability of solvent firms to borrow. Second, a number of papers have examined the transmission of shocks through input-output relationships. These capture production relationships between sectors, but do not take into account the interaction with financial variables, firmlevel heterogeneity and behaviour. Third, some papers use structural closed-form models with microeconomic heterogeneity to model aggregate responses to the shock (Gourinchas et al., 2020). This approach shares the same spirit as this paper with an emphasis on microeconomic behaviour, but without the interactions of degree of heterogeneity included in the CAB model Fourth, Sharma and coauthors (2020) apply the Mark0 agent-based model to understand the COVID-19 shock, showing a wide variation of dynamics for the same initial shock. Pichler and coauthors (2020) apply an agent-based model with 
sectoral inventory buffers and critical and non-critical inputs to assess the impact of the COVID-19 crisis and alternative sectoral re-opening policies.

Section 1 sets out the main features of the CAB model and how it is used to simulate the impact of the Covid-19 shock. Section 2 assesses the impact of the COVID-19 shock with the Coronavirus Job Retention Scheme (CJRS) and a credit guarantee scheme and compares it to a no-policy scenario.

\section{Background - the Corporate Sector Agent-Based (CAB) Model}

This paper applies a new Corporate Sector Agent-Based (CAB) model, a model that was specifically designed to explore the economic impact of the COVID-19 crisis. The construction of the model and its main features are explored in detail in Hillman et al. (2021).

\section{An agent-based model of the corporate sector}

Agent-based models (ABMs) simulate the interaction of autonomous but connected agents and generate emergent aggregate behaviours difficult to predict from a study of the components in isolation. Complexity theory suggests that such models may be particularly useful when the economy is faced with a large shock such as Covid-19, where the behaviour and interactions of the large number of heterogeneous firms could generate emergent aggregate properties that have no simple relationship to individual behaviours (OECD, 2017). Agent-based models are beginning to be applied through large-scale calibrations to a range of economic policy problems (Chan-Lau, 2017[1]; Baptista et al., 2016[2]), including Covid-19 (Pichler et al., 2020)

The CAB model takes into account the effects of the heterogeneity of firms; interactions between firms across a realistic customer-supplier network; with rule-of-thumb behaviour; and bankruptcy constraints. Firms are connected through a supply-chain to suppliers and to individual consumers or business customers. Firms make profits from selling outputs produced using capital, labour, and intermediate goods, which are managed through inventories. There are hiring and firing costs to adjusting labour, and minimum employment units so firms cannot adjust their wage-bill immediately or smoothly. Expected sales are based on aggregate conditions and firm-specific sales. ${ }^{2}$

When firms are hit by a negative demand shock, they scale back demand for intermediate inputs and adjust labour if the shock is expected to last. Firms continue to pay some fixed costs so profits may turn to losses: companies will run down their cash reserves and may resort to borrowing. However, firms face a borrowing limit and fail if they need to borrow and reach the credit limit. Firms that fail fire their workers, while their customers look for alternative suppliers that are able to meet their needs.

A key feature of the $C A B$ model is the large-scale data-rich approach to calibration, which provides a realistic picture of the real-world dynamics of the economy. Firm-level balance sheet data are drawn from ORBIS (Pinto Ribeiro, et al., (2010), Gal et al. (2013)), and industry-level statistics from the OECD Structural and Demographic Business Statistics (SDBS), the OECD STAN Database for Structural Analysis and the OECD Input-Output tables. The supply-chain network is calibrated using business-tobusiness (B2B) transactions dataset from the National Bank of Belgium (NBB). A novel algorithm, building on (Henriet et al., 2012), is used to construct a network to match the empirical distribution of the network

\footnotetext{
${ }^{2}$ The version of the model applied in this paper assumes: inventories and labour are managed through partial adjustment processes; expectations are firm-specific and use a exponentially-weighted moving average of past firm sales; $5 \%$ of supply links are 'critical' (ie the customer requires a fixed ratio of a critical input in its production recipe and it cannot substitute inputs from other firms should the supplier fall short); in the event of supplier failure a customer has a $50 \%$ chance of successfully 'rewiring' to a replacement firm each month. For computational reasons, the model is simulated here using around 5,000 firms.
} 
connections by firm, sector, upstream and downstream connections and by firm size, allowing for heterogeneity in connections between firms within the same sector.

As observed in the data, many firms in the model have very few suppliers and customers: the median firm has only 6 suppliers and 3 business-to-business customers. This implies strong interdependencies between specific firms. However, the distribution of connections is highly skewed and some - typically larger firms - having a rich network of counterparts. Most firms do not sell to the final consumer but only supply intermediates to other firms. Many of these connections are to other firms within the same sector. Figure 1 shows two examples of network structures that exist in the model economy: in the left panel, the firm indexed "1813" is in a simple network, selling directly to final demand with one supplier from the Wholesale and Retail Trade sector that in turn has 3 suppliers. By contrast, the firm in the right panel, indexed "1814", is a business-to-business firm with direct customers in Human Health Services and Social Work and Business Activities. It buys from one major supplier so is vulnerable to that firm, but that supplier has 8 suppliers of its own producing similar goods so it has a more robust supply chain.

\section{Figure 1. Examples of UK customer-supplier network structures in the CAB model}

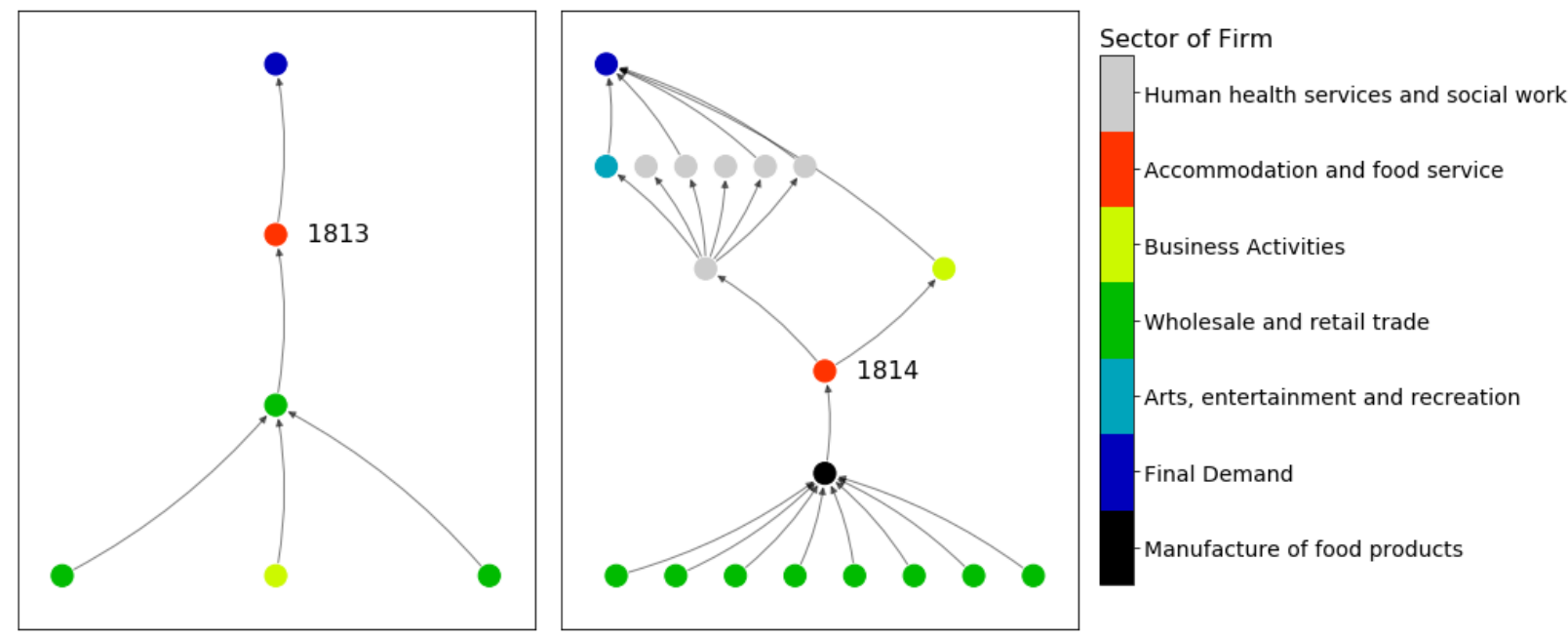

Note: Each panel shows the most important up and downstream connections for two firms within the same sector Accommodation and Food Service activities, as generated by the network algorithm.

The structure and nature of interactions between firms and firms' rule of thumb behaviour amplifies the effect of final demand shocks and generates substantial persistence and overshooting. Individual firm failure is complex and rarely results from a simple a "domino" effect, but rather the accumulated impact of multiple shocks. Firm failureis sensitive to the exact situations and interconnections of customers and suppliers. Very large shocks can lead the economy to cross a "tipping point" with large macroeconomic impacts (Hillman et al., 2021).

The dynamics of the economy depend on a wide range of features such as the customer-supplier network, firms' production and balance sheet characteristics, the ability to find new suppliers, borrowing constraints and the feedback from wages to consumption. In some cases, there are threshold effects in the sensitivity of the dynamics of the economy to these factors.

Firms' fragility is determined by their balance sheet positions and their ability to adjust costs. Firm size measured by turnover (gross output) is very skewed with a small number of very large firms (Figure 2). The median firm has earnings before interest, taxes, depreciation, and amortisation (EBITDA) to turnover ratio of $7 \%$. On average, firms hold cash equivalent to around three months of turnover, but there is a large tail of financially weaker firms, while a small number of firms have very strong positions. Cash reserves 
also vary across sectors, with Manufacturing and Wholesale and Retail holding less than average and firms in Art, Entertainment and Recreations, and Information \& Communication holding more than average. Firms vary widely in the share of intermediate inputs in final output, which determines how easily they are able to adjust their costs. A small share of firms is highly leveraged. Overall, some firms are vulnerable to cashflow shocks while others are relatively resilient. One observation is that the UK ORBIS data has a significant number of firms reporting very weak financial positions or consistent losses: many of these appear to be the unconsolidated entities that are part of or supported by parent companies and are reported to be going concerns in their annual statements, but it is difficult to identify these firms systematically in the data. ${ }^{3}$

\section{Figure 2. Firm size and financial strength vary widely and is skewed}
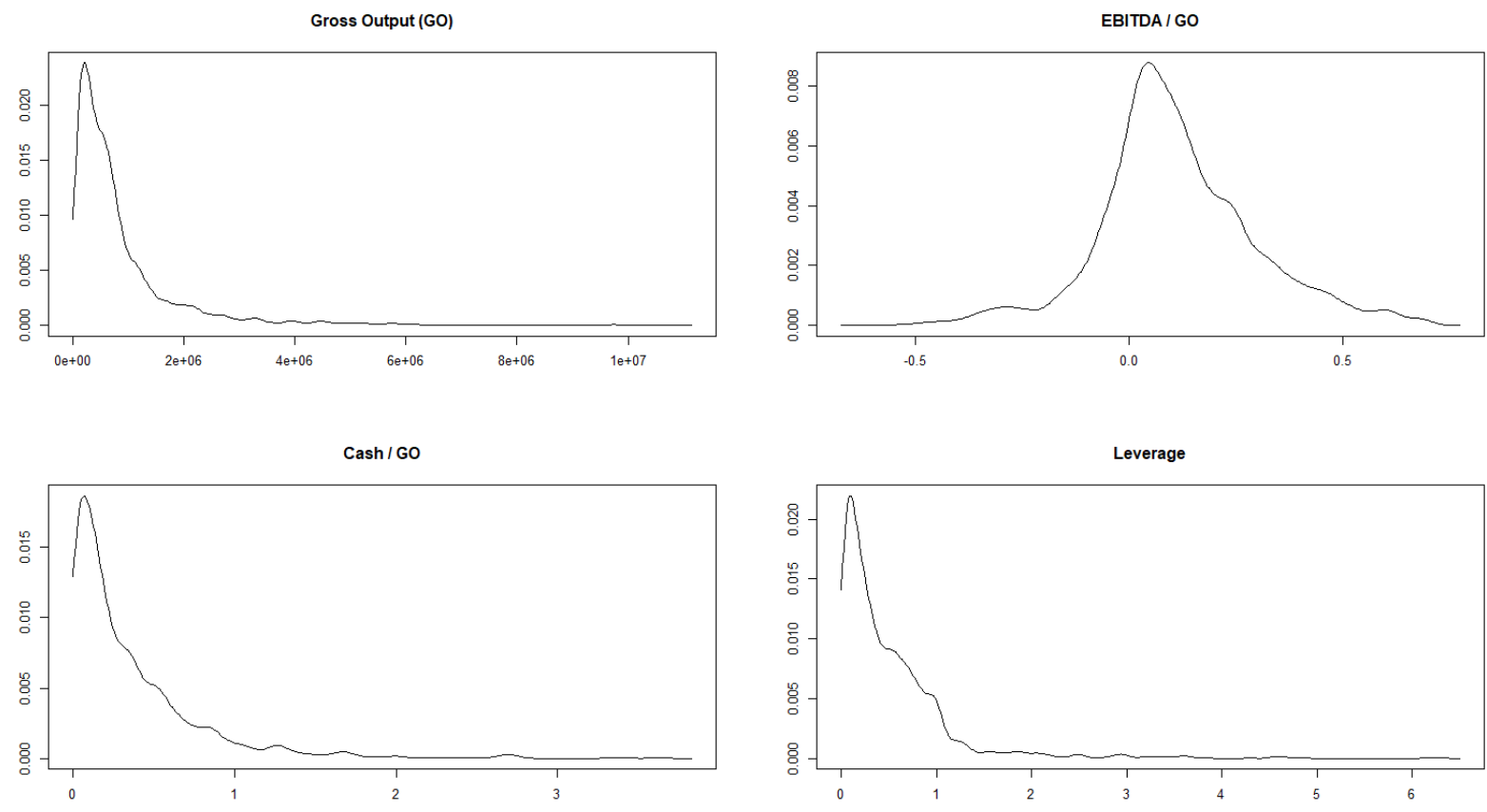

Note: $G O=$ Annual gross output (GBP), EBITDA = Earnings before interest, taxes, depreciation and amortisation, Cash = Firms' reported cash holdings, Leverage $=$ total liabilities divided by total assets. The charts show the empirical probability densities. All charts show the distribution of each metric after trimming the lower and upper $1 \%$ tails because of some extreme outliers.

A key issue is the determination of firm failure. The CAB model uses a highly simplified representation: firms fail when they have negative cashflow and are unable to borrow because they have reached a borrowing ceiling. This ceiling limits additional borrowing to an amount linked to the firm's annual turnover. In reality, banks are likely to use a range of financial ratios and make an evaluation of the viability of the business. However, there is very little empirical guidance on how to model these decisions. As noted by Banerjee et al (2021), there is also surprisingly little known about actual firm level failure processes. These are areas where further research would be warranted. The approach in the CAB model differs from models where firm failure is triggered by negative cash flow alone and firms cannot borrow (Demmou et al., 2021).

\footnotetext{
${ }^{3}$ The final input dataset for the model has undergone a basic data cleaning procedure, but there is no systematic attempt to exclude firms that appear unprofitable or financially weak given that this could include both unconsolidated entities supported by parent companies or genuinely weak firms and it is difficult to disentangle these two types of firm.
} 
Trade credit also plays an important role in some industries and can be a key risk for suppliers if firms default (Jacobsen and Schedvin, 2015).

\section{Modelling the Covid-19 shock}

The Covid-19 shock in the United Kingdom is modelled as the impact on Gross Value-Added (GVA) of the different phases of national lockdown between March 2020 and 2021, together with intervening restrictions and the impact on behaviour of fear of the virus. A "no shock" counterfactual scenario assumes that the economy would have grown at $1.5 \%$ annually in the absence of the shock and in line with recent trends.

Unobserved exogenous final demand shocks are set so that the CAB produces output data that matches the observed monthly sectoral output data from the National Accounts up to January 2021 based the policies that were implemented (Figure 3). ${ }^{4}$ These final demand shocks include shifts in the relative demand for products and an overall reduction in spending during the Covid-19 episode. ${ }^{5,6}$ Exogenous final demand is assumed to have fallen most in activities requiring face-to-face interactions or linked to on-site work. An alternative approach to the Covid-19 shock would have been to model some of the shock as a supply shock.

\section{Figure 3. Sector exogenous final demand shocks used in the simulations}

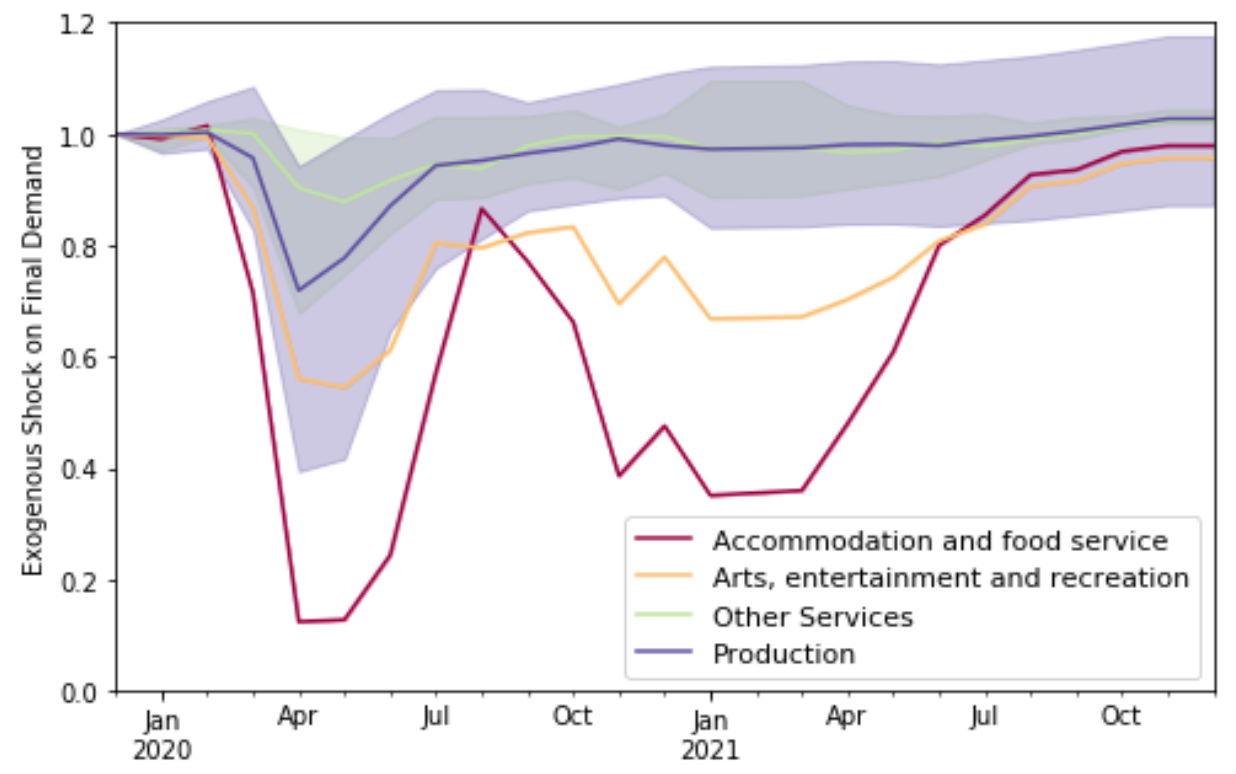

\footnotetext{
4 The CAB model uses as inputs (unobservable) exogenous shifts in demand for final products and endogenously generates falls in output that match this. Exogenous final demand shocks may differ from endogenous final demand shocks taking into account the feedback of wages to consumption and the model dynamics. The calibration is made by shifting the size of observed gross output falls by a common factor to generate estimates of exogenous final demand in the model that broadly match observed gross output. Across sectors, this matches output reasonably closely in most cases.

${ }^{5}$ For example in April 2020, the biggest falls in final demand were seen in Accommodation and Food Service Activities $(-83 \%)$, Manufacturing of Transport Equipment (-52\%), and Manufacturing of Textiles (-50\%) Some sectors were relatively unscathed, for example real estate final demand never dropped below $99 \%$ of its December 2019 level over 2020.

6 Seasonal effects, such as a shift towards retail at Christmas, are ignored. Their influence is likely to be relatively modest at the high level of aggregation used and effects dominated by Covid-19 shocks.
} 
14 | ECO/WKP(2021)25

Source: Authors'calculations based on CAB model. Source: The two sectors Accommodation and Food Services Activities, and Arts, Entertainment and Recreation are shown separately. The coloured swathes show the range of shocks across the two aggregated groups of sectors, Production, and Other Services (all other services except Accommodation and Food, and Arts, Entertainment and Recreation), with the solid lines showing the median shock within the aggregated group. 
While this approach means that the baseline model output matches the observed data by construction, it allows the model to shed light on the dynamics of the economy, construct counterfactuals, explore the role of policies, and make projections for the future. The simulation assumes that the final demand shocks unwind in a linear way by the end of 2021 so that exogenous final demand reaches the level it was at in December 2019. This is below the Counterfactual no-Covid scenario in which output is assumed to be $3 \%$ higher after two years of 'normal' growth.

The baseline simulation assumes the introduction of two policy interventions during the COVID-19 crisis that have been widely used: first, implementation of a timely job retention scheme (JRS) modelled on the Coronavirus Job Retention Scheme (CJRS) and, second, a credit guarantee that effectively raises the amount firms can borrow (see Box). These polices are assumed to last for the duration of the shock. The jobs replacement scheme provides a subsidy to firms for workers not needed to meet production, thereby removing any incentive to fire them and protecting firms' cashflow. Both policies are modelled in a somewhat stylised way, leaving aside many of the detailed features of the schemes implemented.

The CJRS allows firms to adjust their labour costs more easily, furloughing workers they do not need and taking them back as demand recovers. Within the model, this is implemented as allowing firms to adjust labour immediately in full rather than partially and without any financial cost. Workers on furlough receive $80 \%$ of their pre-Covid income so their incomes are largely supported.

The various government-backed loans schemes (including CBILS and Bounceback) are modelled by enabling any firm to borrow up to $25 \%$ of their 2019 turnover. In practice, the largest programme was the Bounceback scheme (see Box) in which firms had to self-verify that they considered themselves a viable business. With the model, the key implication is that firms are allowed to borrow as and when they need it up to this limit. It is assumed firms exhaust their cash reserves, and only then borrow as much they need. This representation is simpler than the actual schemes that were implemented, where firms had to estimate and then apply for how much they wanted to borrow. This implies that the policy as implemented in the $C A B$ model is very efficient in the sense that no firm borrows more than needed to offset liquidity shortfalls. In reality, firms may have borrowed more than needed in part for precautionary reasons or because outcomes were better than expected. As firms did not have to repay loan interest or capital for a year and with no early payment fees, government loans may have been as providing a free option to increase their cash buffer. ${ }^{7}$ Firms were allowed to use Bounceback loans to help pay back existing loans.

\footnotetext{
${ }^{7}$ Within the CAB, firms do not pay (interest or repayment) on new loans over the simulation horizon, which could mean the model overestimates the financial strength of firms in the latter half of 2021. On pre-existing liabilities, each firm pays interest of $5 \%$ a year and $10 \%$ repayment throughout in all scenarios. The ORBIS data coverage on actual interest paid on current liabilities is patchy so for simplicity we take this blanket approach.
} 


\section{Box 1. The Coronavirus Job Retention Scheme and other Covid-19 Policy Interventions}

In response to the Covid-19 pandemic, on 20 March, 2020, the UK Government implemented the Coronavirus Job Retention Scheme (CJRS). This short-time work program allowed employers to furlough their employees during period of low demand. Under the CJRS, workers would continue to receive $80 \%$ of their current salary, up to a maximum of GPB 2,500. Employers have been required to pay social security contributions on furloughed employees' wages since August 2020.

The CJRS retroactively covered wages over the period beginning 1 March, 2020 until 31 May 2020. The CJRS was extended multiple times and is planned to taper from July 2021 with the government contribution dropping from $80 \%$ to $70 \%$ in July and $60 \%$ through to September. Employer compulsory contributions are also scheduled to pick up from zero to $20 \%$ over this period.

On 31 March 2021, there were 4.2 million employments on furlough, down from a peak of just under 9 million in spring 2020. Use of the scheme has varied across sector: in March 2021, 70\% of supported jobs employments were in the Hotels and Similar Accommodation Sector. Firms with 2-4 employees had $34 \%$ of eligible employees on furlough, compared with $8 \%$ among employers with more than 250 employees.

In addition to the CJRS, the UK government has implemented a number of other support programs for businesses, including the Coronavirus Business Interruption Loan Scheme (CBILS), the Coronavirus Large Business Interruption Loan Scheme (CLBILS), the Future Fund, and the Bounce Back Loan Scheme. All of these programs aim to ensure firm liquidity during the course of the pandemic. The Bounce Back scheme enabled small firms access to up to $25 \%$ of their 2019 annual turnover in a $2.5 \%$ interest loan (up to a maximum of GBP 50,000), repayments and interest payments not being due for a year. The CBILS, and CLBILS schemes are designed for larger firms up to $45 \mathrm{~mm}$ (or $>45 \mathrm{~mm}$ for CLBILS) in annual turnover. In all schemes, the loan is between the borrower and a commercial lender. In the CBILS and CLBILS scheme, the rate is set by the lender, but the Bounceback loan is fixed at $2.5 \%$. By the 31 March 2021, the total value of approved facilities was GBP 46.5 billion for Bounceback loans, GBP 23.2 billion for CBILS and GDP 5.3 billion for the CLBILS.

Source: The Job Support Scheme https://www.gov.uk/government/publications/the-job-support-scheme/the-job-support-scheme Changes to the Coronavirus Job Retention Scheme https://www.gov.uk/government/publications/changes-to-the-coronavirus-job-retentionscheme/changes-to-the-coronavirus-job-retention-scheme

CJRS take-up Coronavirus Job Retention Scheme statistics: 6 May 2021 - GOV.UK (www.gov.uk)

Financial support for businesses during coronavirus (COVID-19) https://www.gov.uk/government/collections/financial-support-forbusinesses-during-coronavirus-covid-19?priority-taxon=09944b84-02ba-4742-a696-9e562fc9b29d

Loans statistics HM Treasury coronavirus (COVID-19) business loan scheme statistics - GOV.UK (www.gov.uk)

\section{Insights on the impact of Covid-19}

\section{What would have happened in the absence of policy}

In the absence of any policy response, the CAB model suggests that Covid-19 shock would have led to a sharp fall in output during the spring of 2020 , followed by a recovery and then a shallower second dip around the turn of the year during the third national lockdown. The Covid-19 shocks to final demand would lead firms to scale back their output, intermediate purchases and employment, amplifying the initial shock as the impact rippled through the supply chain The peak fall in GVA of $25 \%$ compared to its pre-shock level somewhat amplifies the original shock to final demand (Figure 4). The recovery would then have been somewhat slower than the recovery in exogenous final demand as firms adjust their expectations, 
inventories are adjusted and the responses propagate upstream. Firm failure would have led some workers to lose their jobs, but a permanent loss of output is mitigated by the ability of surviving firms to scale up.

If exogenous final demand recovers to its December 2019 level at the end of 2021, activity would still be 3\% lower than in December 2019 and 5.5\% lower than the "no shock" normal times counterfactual. This likely overstates the true "permanent" effect beyond this horizon as the current version of the model does not include investment, firm entry or price-adjustment that could mitigate this effect in the longer term.

Figure 4. Without policy, Covid-19 would have led to a very severe and lasting falling in output

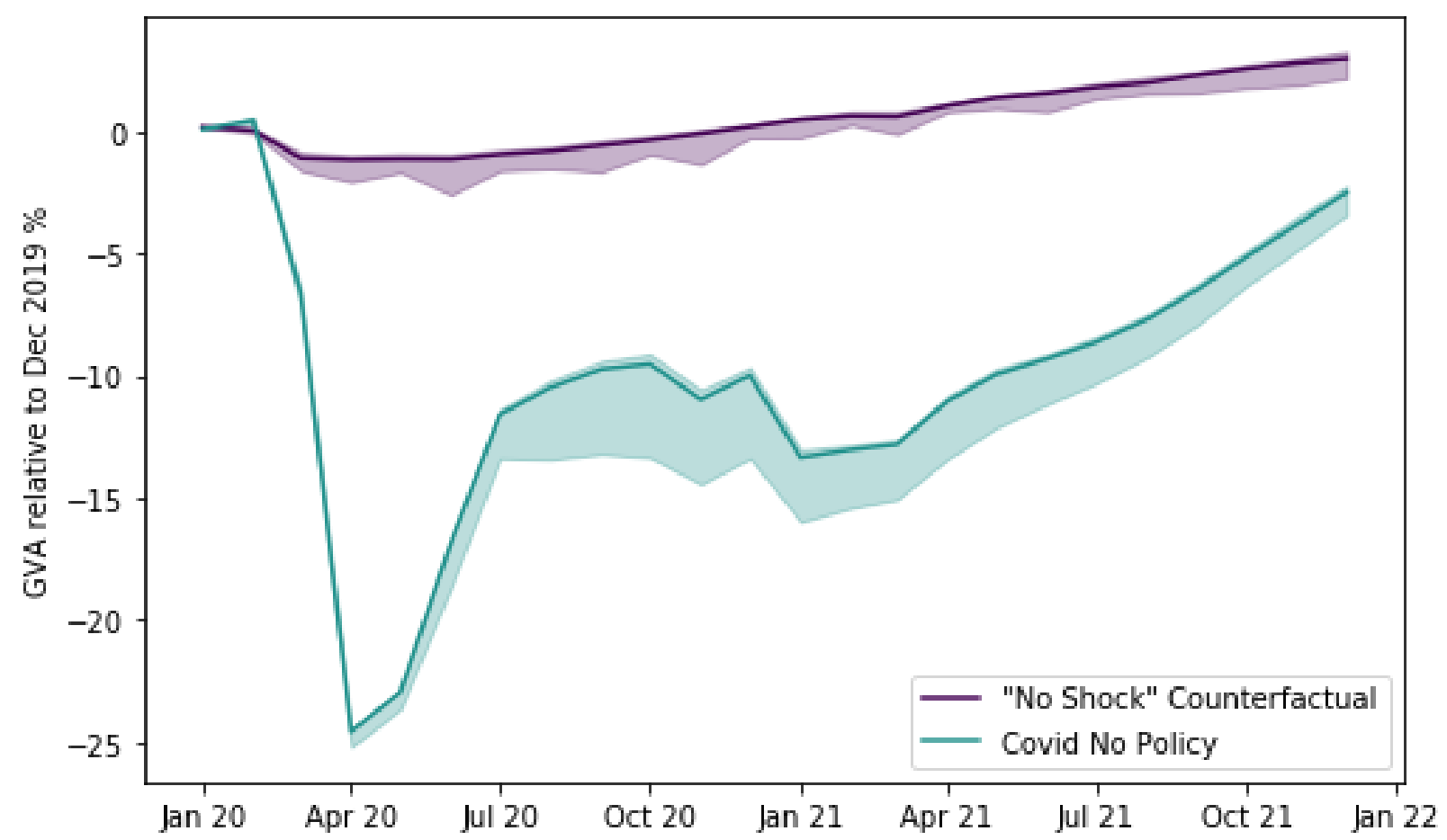

Note: The range indicates the amount of variation that comes from different initial networks.

Source: Authors'calculations based on CAB model.

The Covid-19 shock would have led to over $15 \%$ of firms failing by the end of December 2021, an increase of around $50 \%$ compared to the no-Covid normal times counterfactual. This increase in the rate of failure appears of a similar magnitude to the impact of the Global Financial crisis when insolvencies in England and Wales increased by around $50 \%$ of their pre-crisis rate. Firm failure would have varied significantly across sectors, up to more than one quarter of firms in the Accommodation and Food Services sector and a fifth of firms in manufacturing (Figure 5). 
Figure 5. Failures would have increased by a half with up to a quarter of firms failing in some sectors

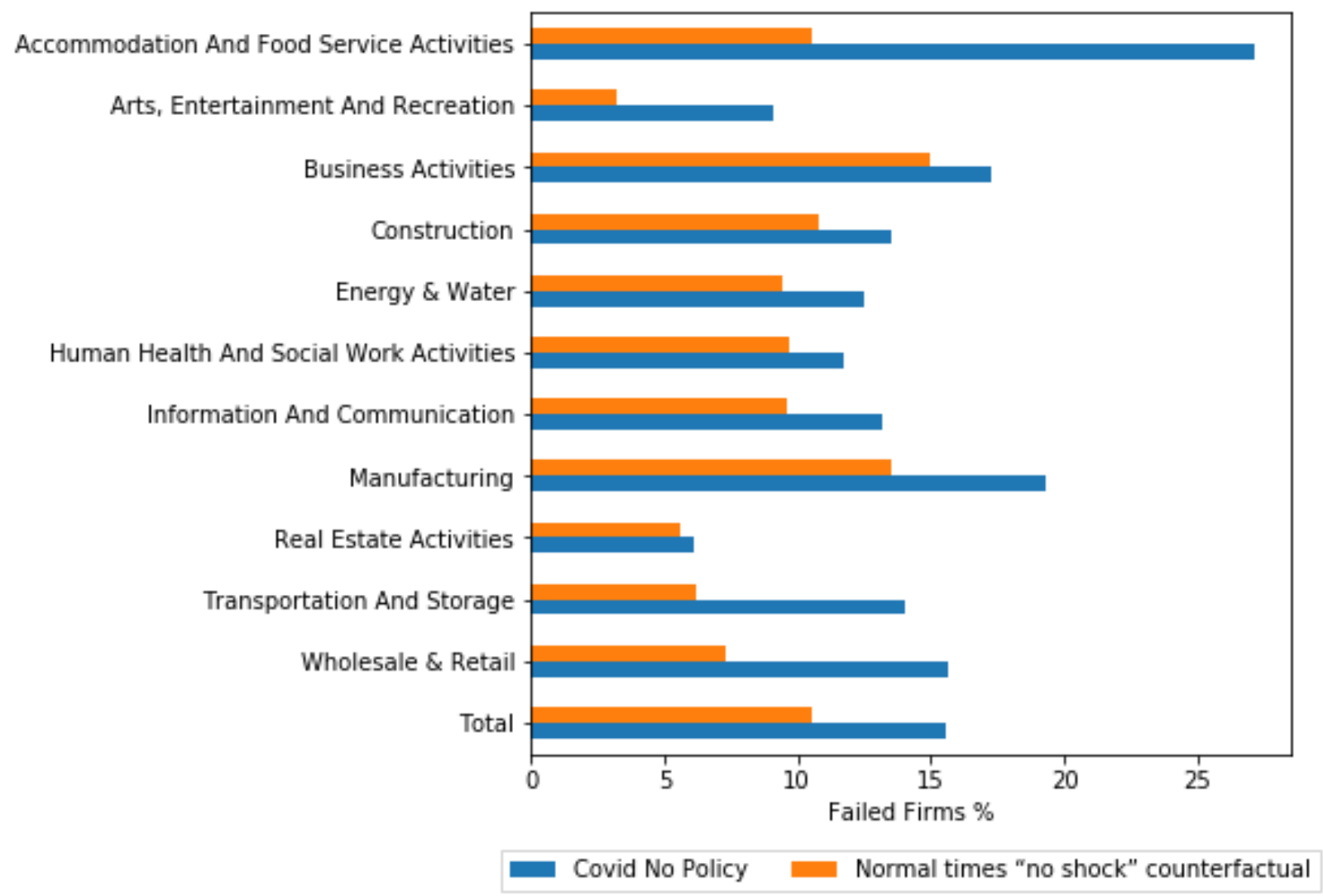

Source: Authors'calculations based on CAB model.

The failure of firms as a result of Covid-19 in the absence of policy depends on a range of factors and varies significantly by sector and within sectors. A key insight from the CAB model is that individual firm failure is multifactored and depends on a wide range of factors such as the shock to demand for the products it produces, how reliant it is on particular customers and suppliers and, the size of cash holdings and the ability to adjust intermediate inputs and employment (Hillman et al., 2021). Small differences in the cash position of specific firms relative to the shocks they face can make a critical difference. In terms of firms' connections, an identical firm with different supply-chain connections could survive or fail depending on exactly what happens to firms to which it is connected. The impact of the shock depends critically on the performance of weaker firms.

A commonly-voiced fear is that large shocks will generate a "cascade" of failures as one failure directly triggers another. ${ }^{8}$ While this can happen within the $C A B$ simulations, cascading firm failures are relatively rare because many firms have several suppliers and customers). Rather, firm failures tend to arise through the accumulation of negative developments at firm level. Firms' experience of the Covid-19 shock depends on a wide range of factors and specific events, such as the failure of a specific supplier, can have a large

\footnotetext{
8 In the UK, the risk of failure of firms like Carillion generated a lot of headlines about the broader impact that emphasised the supply chain and financial connectedness ramifications, see for example Financial Times (2018)
} 
impact on the outcome, but these effects are mediated by many features of the firms' production processes, balance sheet and supply network.

Figure 6 shows the fate of a single firm (see Hillman et al, 2021 for more examples). The firm is a textile manufacturer and only sells to other businesses. At the start of the simulation, the firm is in negative equity but its cash flow is positive and it is heading towards solvency. Following the Covid-19 shock in March 2020, it experiences a drop in sales and loses one of its 20 customers. A month later, one of its 14 suppliers fails: this firm produced a critical product and so production halts in May and June until an alternative is found. Despite scaling back purchases and staff, the company cashflow turns negative and it is forced to borrow heavily in June 2020. Even when the firm is back to full production ability, its sales are lower due to weak demand and it continues to make use of the CJRS scheme rather than firing workers and it continues to run down inventories in the latter half of 2020. These boost cashflow. During 2021, as demand slowly recovers, it begins rebuilding inventories and slowly bringing back workers from furlough. By December 2021, the firm has no workers on furlough and its monthly cash flow is back to pre-Covid levels. Although its liabilities increased with the borrowing it needed in June 2020, its overall equity has improved turning positive around October 2020 and returns to a path of improving cashflow.

Figure 6. Example of a viable firm that makes use of both policies in the Covid shock

Firm: 29, Sector: Manufacture of textiles
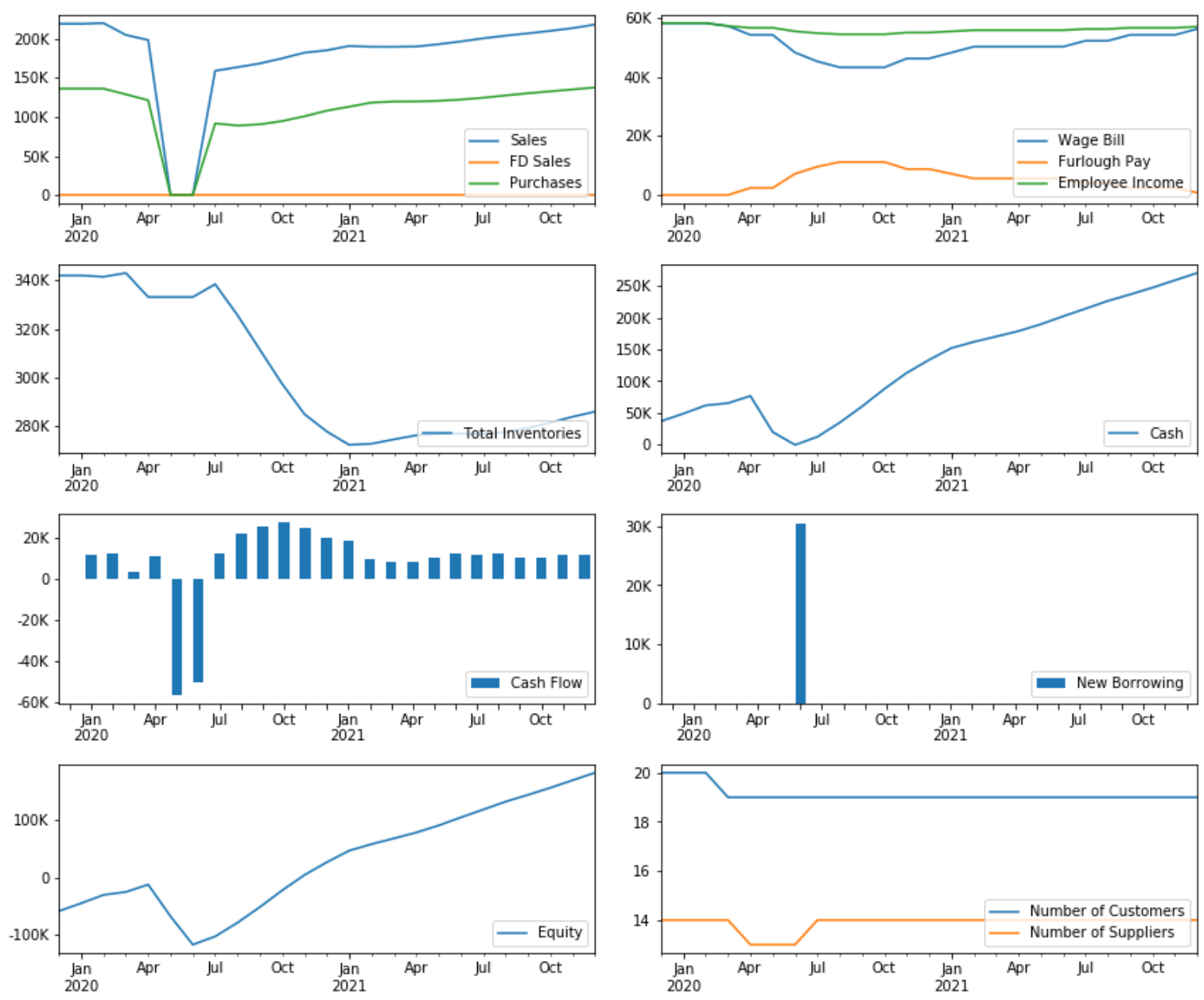

Source: Authors' calculations based on CAB model. See text for full explanation. 
The share of firm failures by sectors is broadly related to the size of shocks with sectors more exposed to Covid-19 disruptions more likely to experience a higher rate of firm failure compared to normal times (Figure 7). However, the effects are not perfectly correlated with some sectors being relatively robust conditional on the size of the exogenous final demand shock. This reflects not only the relationship between the exogenous final demand sock and the ultimate effect on demand in that sector, but also differences in production structures and financial robustness. Failing firms tend to be smaller firms, confirming the fragility of SMEs due to weaker balance sheets and less diversified supply-chain relationships. As shown in Figure 8, firms that fail tend to have lower productivity. Given that firms that fail tend to be relatively small in terms of turnover, this suggests that the firms that fail may be less productive and less profitable than the average.

Figure 7. More firms would have failed in sectors facing bigger demand shocks

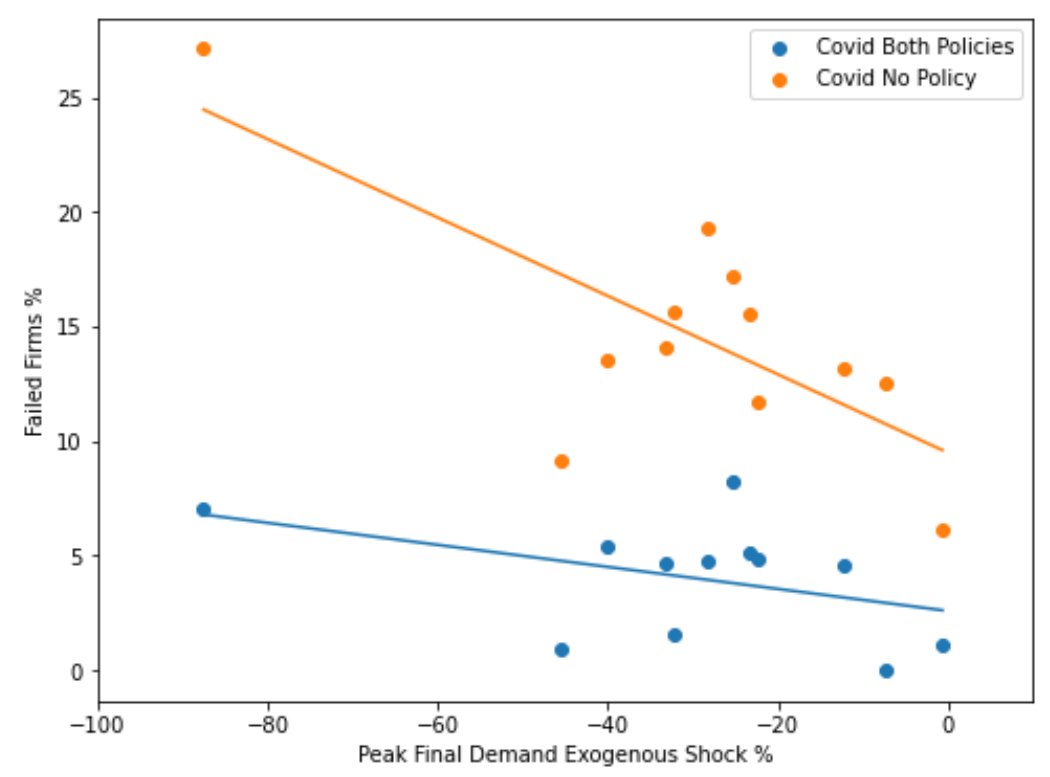

Source: Authors' calculations based on CAB model. Each dot in the left panel shows the peak exogenous demand shock versus the percent of failed firms for each sector, with and without the modelled policy support. 
Figure 8. Firms with lower productivity are more likely to have failed

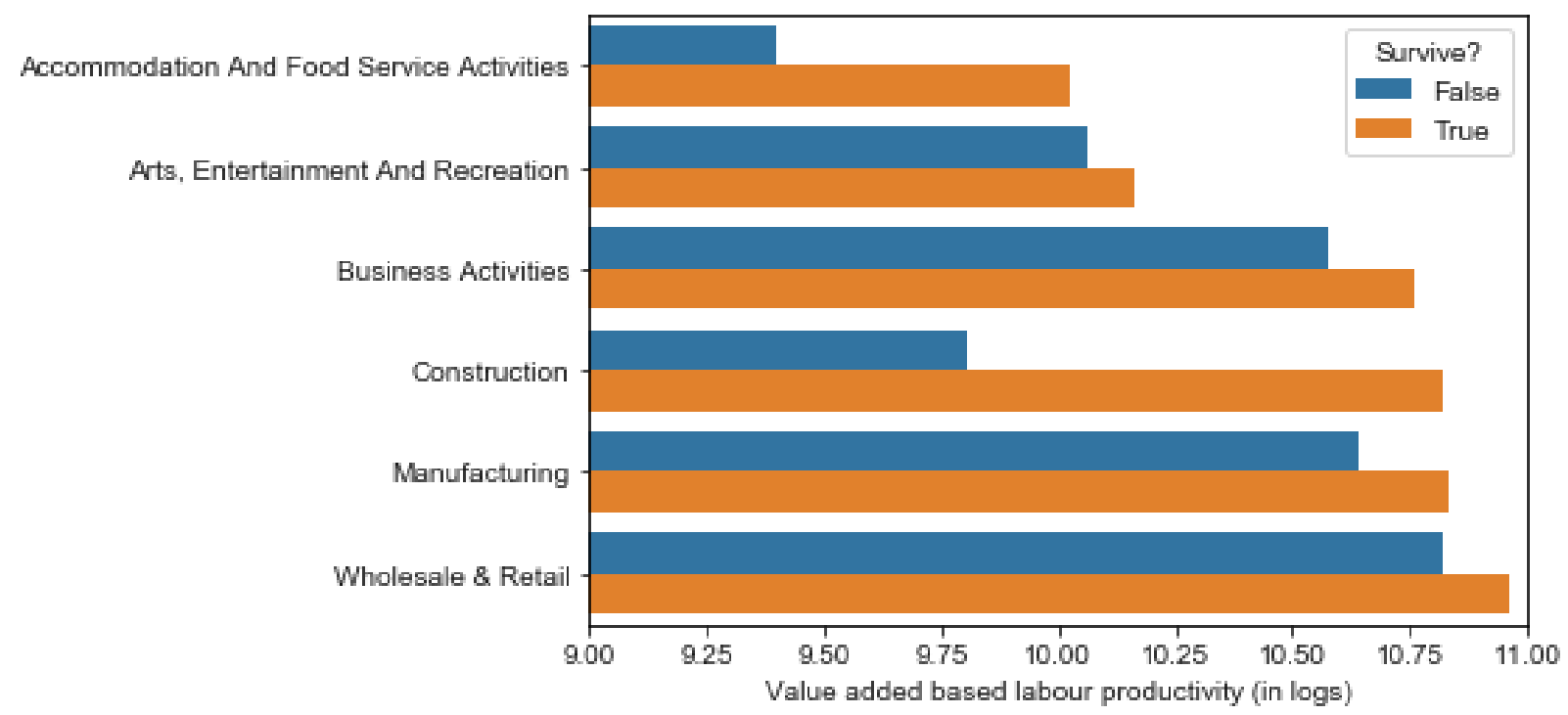

Source: Authors'calculations based on CAB model. The bar shows the (log) labour productivity for firms who survived (assuming the policy measures in place) versus those that failed during 2020-2021. The productivity measure is based on value-added and the number of employees as computed by the OECD (Gal, 2013).

These results depend on the exact parameterisation of the model chosen and could differ in alternative configurations. In particular, the sensitivity of firm failures to the shocks is sensitive to the assumptions on whether firms are able to borrow (Hillman et al., 2021). In the counterfactual and the no policy scenario, it is assumed that firms cannot borrow and so fail when they run out of cash. While this is not fully realistic, it serves as a benchmark for the impact of allowing firms to borrow significantly under the policy scenario. Less restrictive borrowing conditions would result in fewer firm failures both in normal times and with the Covid-19 shock. Given the significant number of apparently very weak firms in the ORBIS data that may in reality be "going concerns" due to external support, it is likely the CAB model overestimates the initial number of failures. ${ }^{9,10}$

\section{The government's policy support has been highly effective}

The government's policy response has been highly effective in supporting output and avoiding firm failure due to Covid-19 (Figure 9). In terms of GVA, while the initial trough was roughly as deep as would have

\footnotetext{
${ }^{9}$ While the average of the reported rates is $5.3 \%$ a year, failures do not build monotonically over the two years in the counterfactual: in the first year $6.9 \%$ of firms fail and in the second $3.7 \%$ fail. Adjusting for this potential overestimate in the first year, a more realistic counterfactual estimate would be around $4 \%$ a year. This compares to another recent estimate of $5.26 \%$ for the UK in a non-COVID counterfactual for 2020 (Gourinchas et al, 2021), in which failure is also measured by firms running out of cash. Note that when we look at excess failures, this effect nets out so that the model would still expect $5.1 \%$ excess failures in the case of the Covid scenario (with no policy response) compared to the counterfactual (50\% more than the $10 \%$ expected in the counterfactual).

10 This may also reflect the limitations of using a single year's balance sheet position (2018) which may cast some firms in an unduly weak light. Alternative ways to address this issue would be to run the model for a number of periods before the shock in order to allow weak firms to fail, to remove extremely weak firms from the sample or to capitalise the "going concerns" sufficiently to emulate the support they have from their guarantor
} 
been the case in the absence of policy, the initial recovery was swifter to reach a level over summer 2020 around $5 \%$ below the 2019 level rather than $10 \%$ lower in the case with no policy shown in Figure 9 . The second trough is shorter and shallower due to policy support. Further, the support implies that activity could recover to just $2 \%$ below the no-Covid scenario after two years and reach the 2019 level by later 2021 if exogenous final demand fully recovers.

Figure 9 also shows that the range of outcomes with policy is far narrower than in the "no policy" case: this shows how policy contributes not only to improving the central outcome but also makes the outcome more robust by reducing firm failure with the knock-on effects this can have on other firms and feedback effects this can generate. ${ }^{11}$ The distribution is also more skewed in the absence of policy, so the policy partly acts to reduce the risks of more extreme outcomes.

The CJRS scheme allowed firms to continue to pay workers through the downturn that they would otherwise have let go, reducing the negative feedback to incomes and consumption. At the same time, this support and the increased ability to borrow allowed more firms to withstand a period of negative cashflow, avoiding the repercussions on their customers, suppliers and workers of firm failure.

\section{Figure 9. With massive policy support, the depth and persistence of the Covid-19 loss of output} has been reduced

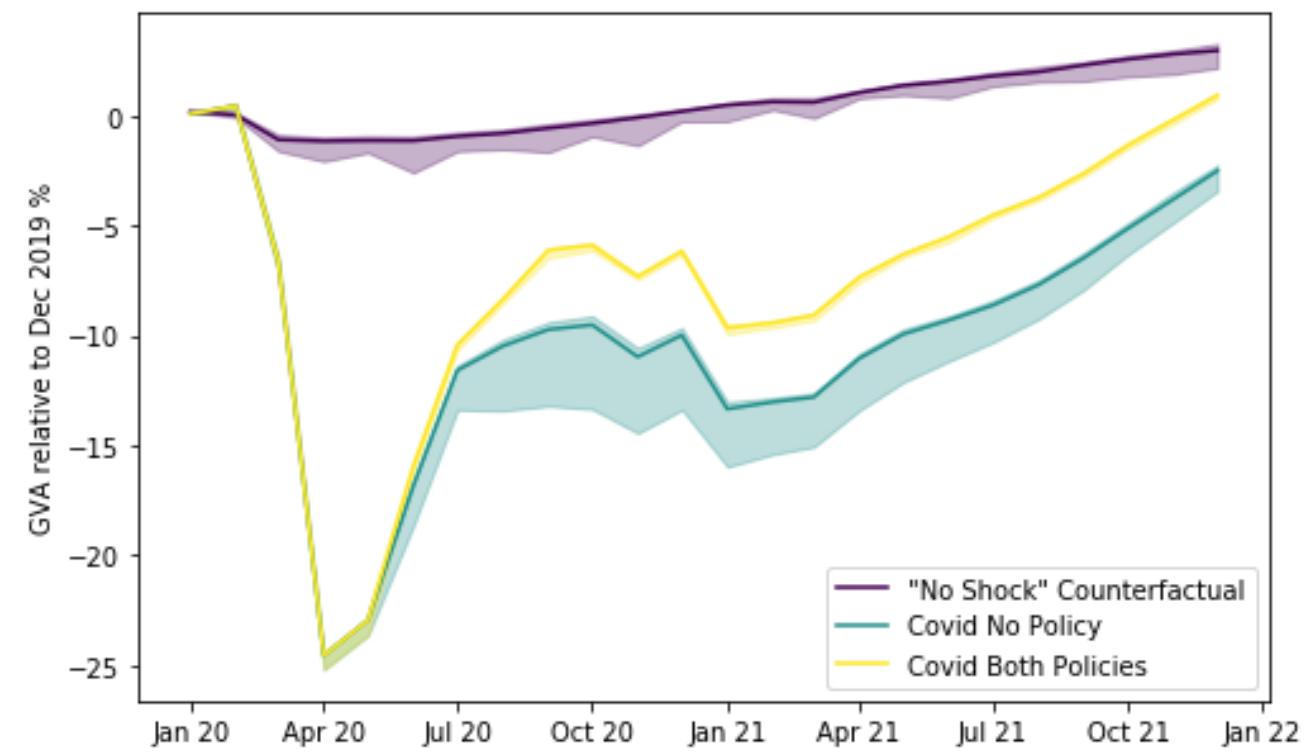

Source: Authors'calculations based on CAB model.

Indeed, the rate of firm failures in the policy scenario is lower not only than in the "no policy" scenario but also lower than would have been the case in normal times (Figure 10). Around $5 \%$ of firms would fail in the first two years of the Covid-19 shock with policy supports, compared to around $10 \%$ in normal times and $15 \%$ if there had been no policy response to the shock.

\footnotetext{
11 This range comes in the first instance from different firm networks but can partly be seen as standing from other uncertainties or idiosyncratic factors. Since the firm network is uncertain from the policymakers' perspective, this is a relevant consideration from the government's perspective.
} 
Figure 10 shows the profile of failures per month for the "No Covid" normal times counterfactual, and the Covid scenario with and without policy support. ${ }^{12}$. Without policy, there would have been a big jump in firm failures May 2020, as firms ran out of cash, and failures would have remained high until early 2021. By contrast, with policy, failures would have been initially been driven to a very low level as support came on stream and then only slowly have picked up somewhat noisily to around normal levels. The recovery, combined with weaker firms having been pushed to failure in the no policy case, suggest that firm failures would remain relatively lower during the later part of 2021.

\section{Figure 10. Firm failures have been reduced by policy support}

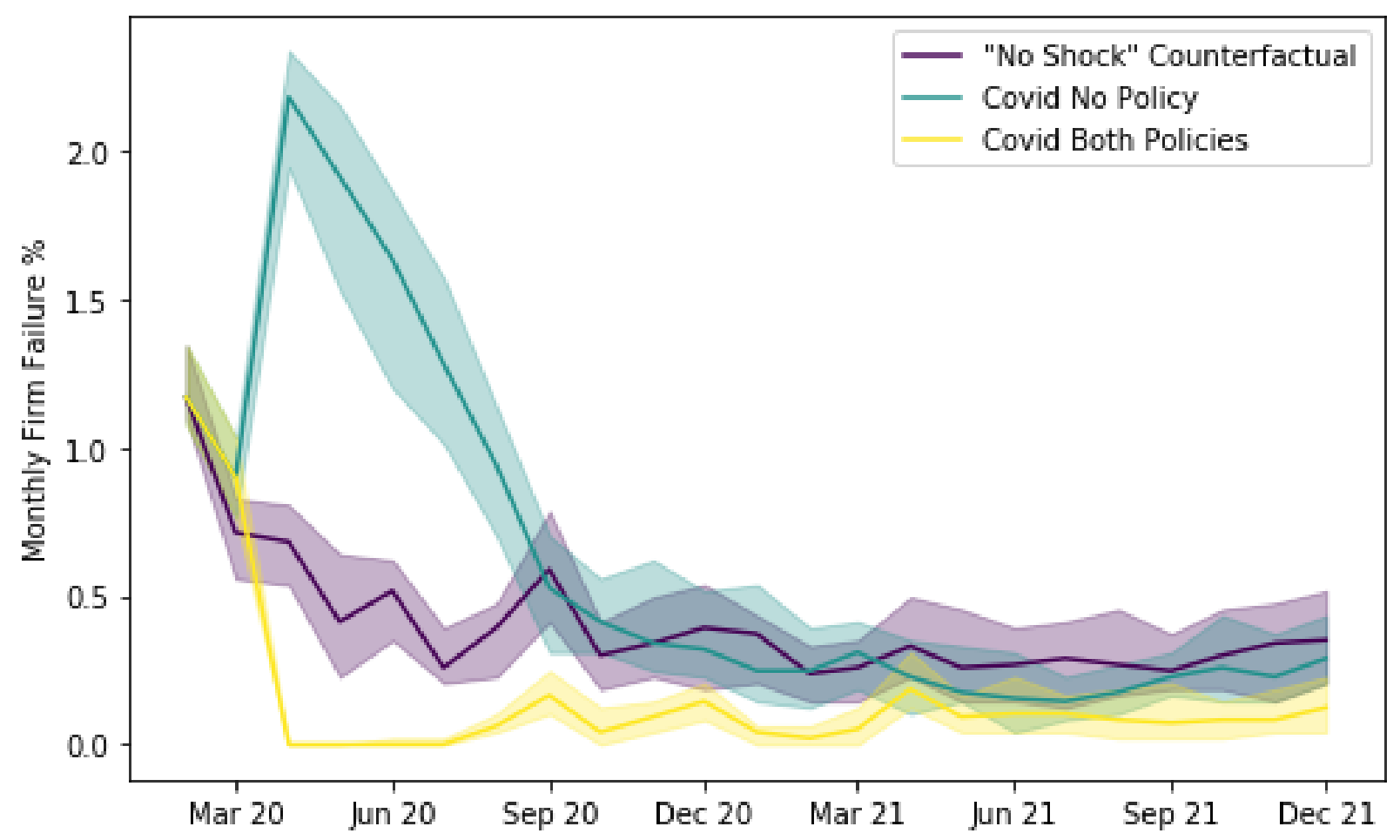

Source: Authors' calculations based on CAB model.

This counterintuitive outcome reflects in part that the policy support has been strong enough to both largely avoid additional failures as result of the Covid-19 shock and to protect some firms that would have otherwise failed by providing them with a subsidy for workers that they do not need and increasing their ability to borrow. As Table 1 shows, almost all firms that would have survived without the shock make it through Covid-19 thanks to the policy support. Looking at firms that would have failed in normal times, about half would survive, despite the shock, as the result of better access to credit and the CJRS.

\footnotetext{
12 The chart shows failures of firms who are not "going concerns" at the start of the simulation in order to show more clearly the impact of the crisis.
} 
Table 1. Firm failures are lower as policy supports have protected firms hard hit by Covid-19 and also supported firms that were already vulnerable

$\%$ share of firms

\begin{tabular}{l|c|c}
\hline & \multicolumn{2}{|c}{ Covid-19 and policy } \\
\hline "No Shock" Counterfactual & Survived & Failed \\
\hline Survive & 89.1 & 0.4 \\
\hline Fail & 5.8 & 4.7 \\
\hline
\end{tabular}

Source: Authors' calculations based on CAB model.

The profile of failures predicted by the CAB model is in line with the available data on insolvencies to date that shows a fall since the start of the Covid-19 crisis (Figure 11) and insolvencies remaining low until the latest data in April 2021 (Insolvency service, 2021). It should be noted that the simulation is calibrated only to UK output developments to date and not firm failures, so the predicted rate of firm failure is entirely generated by the dynamics of the model and so provides a genuine test of the predictive power of the model. While some of the fall in insolvencies may reflect administrative complications induced by Covid19 to wind up firms, the model what suggests that this may also reflect underlying developments.

Figure 11. UK insolvencies have fallen so far during the pandemic

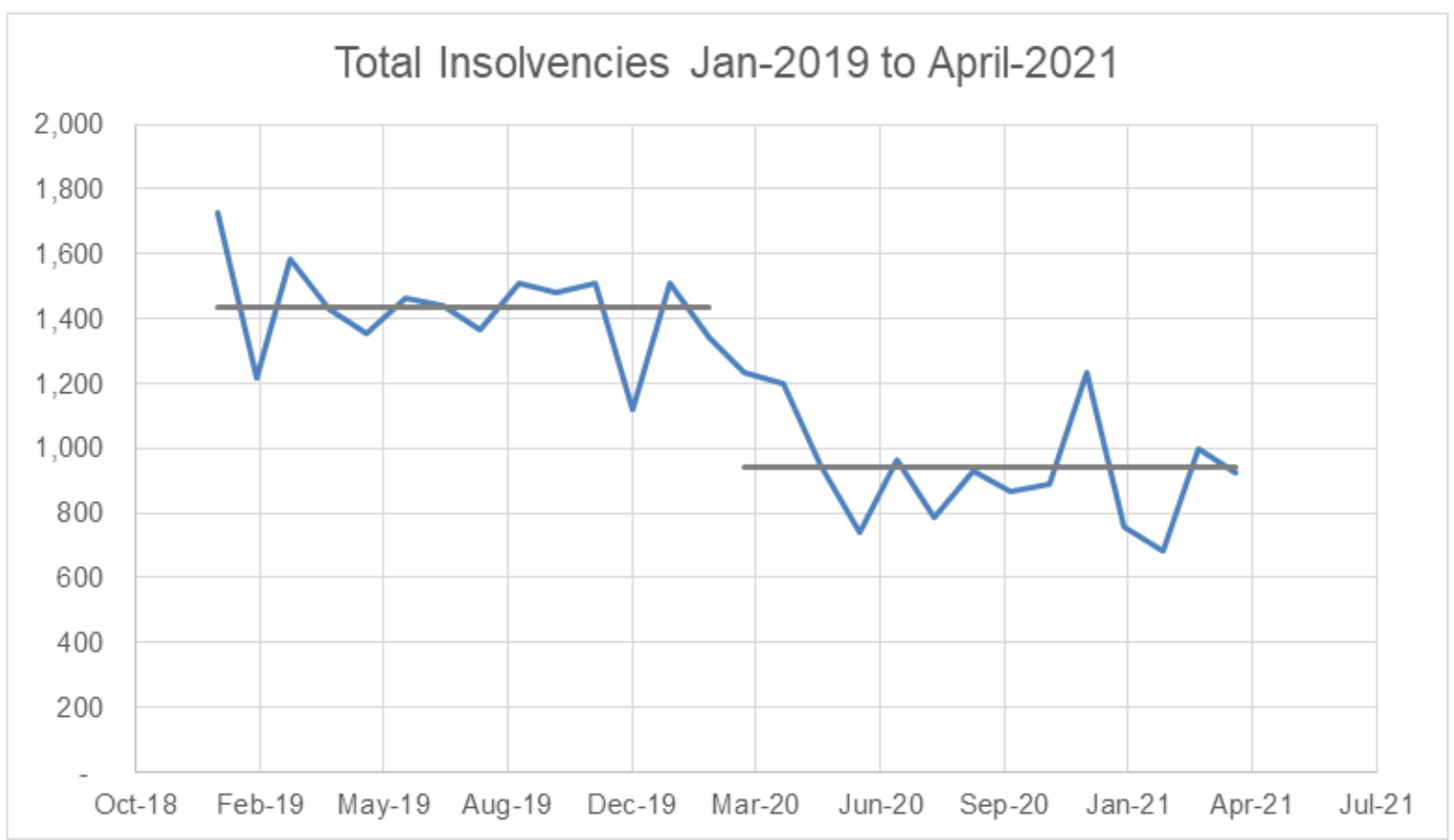

Source: https://www.gov.uk/government/statistics/monthly-insolvency-statistics-april-2021 Total Insolvencies, includes both Compulsory Liquidations, Creditor's Voluntary Liquidations, Administrations, and Company Voluntary Arrangements.

There are a number of reasons for the counterintuitive result that failures may be lower than in normal times. Firstly, exceptional and extensive policy supports, see Box 1, have had a very substantial impact. Secondly, the Covid-19 shock - while extremely severe - could have been far worse with more sectors being deeply affected for a much longer period. The switch to online activities and eventual roll-out of vaccination have helped to reduce the shock and mean that many firms were not severely impacted. With 
many firms having cash reserves of at least 3 months' sales, these were sufficient to allow many firms to weather out the storm. As argued in Hillman et al. (2021), a longer or deeper shock could have triggered negative feedback loops in the model and have led to a much more dramatic and difficult to contain impact. Thirdly, many firms have a degree of resilience due to the ability to reduce a large share of their costs to survive, even if this transmits the impact to their employees, suppliers and overall activity. A large share of output is accounted for by larger firms that tend to be more financially robust and have more diversified and robust customer and supplier networks.

Looking in more detail, sectors that were hard-hit by the Covid-19 such as Accommodation and Food Services have a low number of failures (Table 2) with policy support compared to other sectors. However, these sectors have seen the largest use of government schemes with, for example, $70 \%$ of eligible employees on furlough by the end of February 2021 and 65\% in Arts, Entertainment and Recreation. Overall, failure rates in all sectors are lower than in normal times but the correlation to normal failure rates or to excess failures in the no policy case is low at the sectoral level. 
Table 2. Proportion of firms in each sector failing by end 2021 in different scenarios

\begin{tabular}{l|c|c|c}
\hline \multicolumn{1}{c|}{ Sector } & Normal times Counterfactual & No Policy & Policy \\
\hline Accommodation And Food Service Activities & 10.5 & 24.9 & 6.1 \\
\hline Arts, Entertainment And Recreation & 3.2 & 9.1 & 1.2 \\
\hline Business Activities & 15.0 & 18.0 & 8.1 \\
\hline Construction & 10.8 & 13.1 & 5.3 \\
\hline Energy \& Water & 9.4 & 15.6 & 0.0 \\
\hline Human Health And Social Work Activities & 9.7 & 11.9 & 4.8 \\
\hline Information And Communication & 9.6 & 12.6 & 4.6 \\
\hline Manufacturing & 13.5 & 20.4 & 4.7 \\
\hline Real Estate Activities & 5.6 & 6.7 & 1.7 \\
\hline Transportation And Storage & 7.3 & 14.3 & 5.3 \\
\hline Wholesale \& Retail & 6.2 & 15.5 & 1.9 \\
\hline Total & 10.5 & 15.6 & 5.1 \\
\hline
\end{tabular}

Source: Authors' calculations based on CAB model.

The access to credit has been a key part of the support package. This implies that - consistent with the observed data - some firms have increased their borrowing and leverage during the Covid-19 crisis, even if they have survived (Table 3). For example, in the simulation, 13\% of firms in Accommodation and Food Services would have to borrow by the end of 2021 after having exhausted their cash reserves. Median leverage of firms of Accommodation and Food Services firms who borrowed would have increased from 0.4 to 0.7 of annual sales by December 2021. At the same time, the overall share of firms with negative equity in each sector falls following the Covid-19 shock as the most vulnerable firms are more likely to have failed. So, while more firms are more indebted, there are fewer highly-leveraged firms.

Table 3. Median leverage of firms that borrow and survive during Covid-19 with policy

\begin{tabular}{l|c|c|c}
\hline & $\begin{array}{c}\text { \% of firms in sector that borrow in } \\
\text { pandemic }\end{array}$ & $\begin{array}{c}\text { Starting } \\
\text { leverage }\end{array}$ & $\begin{array}{c}\text { Final } \\
\text { Leverage }\end{array}$ \\
\hline $\begin{array}{l}\text { Accommodation And Food Service } \\
\text { Activities }\end{array}$ & 13.1 & 0.4 & 0.7 \\
\hline $\begin{array}{l}\text { Arts, Entertainment And Recreation } \\
\text { Business Activities }\end{array}$ & 3.8 & 0.3 & 0.4 \\
\hline $\begin{array}{l}\text { Construction } \\
\text { Energy \& Water }\end{array}$ & 5.8 & 0.5 & 1.0 \\
\hline $\begin{array}{l}\text { Human Health And Social } \text { Work } \\
\text { Activities }\end{array}$ & 5.6 & 1.0 & 1.3 \\
\hline Information And Communication & 9.4 & 0.1 & 0.6 \\
\hline Manufacturing & 4.4 & 0.5 & 0.8 \\
\hline Real Estate Activities & 3.5 & 1.0 & 1.5 \\
\hline Transportation And Storage & 12.4 & 0.5 & 0.5 \\
\hline Wholesale \& Retail & 4.5 & 1.0 & 1.6 \\
\hline Total & 4.7 & 0.4 & 0.4 \\
\hline
\end{tabular}

Source: Authors' calculations based on CAB model.

The implied amounts of aggregate borrowing to cover negative cashflow in the CAB model are substantially lower than the observed increase in the debt of the non-financial sector. While some of this may reflect the fact that firms need to maintain some positive cash balances to do business, this would also be consistent with the idea that firms have partly borrowed on a precautionary basis, making full use of the available 
supports in case it was needed rather than only to cover cashflow shortfalls. Nevertheless, higher leverage leaves firms more exposed to future negative shocks.

One reason why firm failure could be higher than these simulations suggest is if some firms experience permanent disruption to their business models: the projections here assume that exogenous final demand returns to its original path. However, in reality, some activities may have been permanently altered. For example, a permanent move towards greater teleworking than in the past could reduce the demand for city centre facilities such as restaurants, coffee shops and hotels. Simulations of the CAB model suggest that applying a large permanent loss to some firms in key sectors could increase the rate of firm failure to a level somewhat higher than in the baseline simulations. ${ }^{13}$

However, many of the firms that could be hit by permanent shocks to their business models were in good financial health initially. Combined with government supports, these firms could survive for potentially a long time without becoming insolvent. This suggests that these firms may cease trading rather than being forced to bankruptcy. While it is difficult to know how many firms have ceased trading in any sector, in part due to reporting lags, the UK Business Insights and Conditions Survey (link) surveys suggests that by October 2020, 7.2\% of firms in Accommodation and Food Services had "permanently ceased trading", although other observations from the same survey series were far lower. According to a recent report, the 'licensed' industry (pubs) experienced $7.4 \%$ of site closures (Alix Partners, 2021). ${ }^{14}$.

While the model assumes that firms that fail exit, it is likely in reality that some of these businesses may be recapitalised or taken over. Many firms that get into trouble see their business continue in some new form that preserves their production and supply-chain links..

The survival of firms due to policy support that would otherwise have failed benefits firms with belowaverage productivity: these "zombie firms" could drag on aggregate productivity in the years ahead. In addition, firms whose business models have been permanently disrupted by Covid-19 could survive for a long time if they were financially in good shape prior to the crisis and accessed policy supports. A risk is that policy support has in part simply delayed, or stored up, the inevitable for these firms and that this could drag on productivity or lead to future financial difficulties.

\section{Designing policy to support firms}

The design of support policies raises a number of considerations. Looking at the impact of each of using the CJRS and different borrowing constraints separately, both work to lower output losses and reduce firm failure. The CJRS alone would have kept failures at a slightly higher level than in normal times (Table 4). By contrast, relaxing the borrowing constraint as assumed is almost as effective in terms of firm failure as both policies together. In terms of output losses, both policies raise output compared by around $2 \%$ if both policies are used (Table 5). The smaller marginal gain of both policies combined shows the interactions between the two policies and they are partly substitutes. The CJRS helps to reduce firms' borrowing, which may reduce long-term risks, but plays a greater role in supporting incomes and consumption.

\footnotetext{
13 These simulations are not reported in this paper.

14 This likely include chains who had closed individual pubs, and so would not count as a company going out of business.
} 
Table 4. Firm failures under alternative policy assumptions

$\%$ share of firms

\begin{tabular}{l|c|c|c}
\hline Borrowing ceiling (increase in borrowing as \% of turnover) & $\mathbf{0 \%}$ & $\mathbf{5 \%}$ & $\mathbf{2 5 \%}$ \\
\hline "No Covid" Counterfactual & 10.6 & & \\
\hline Covid, No Furlough (CJRS) & 15.6 & 10.0 & 5.5 \\
\hline Covid with Furlough (CJRS) & 11.6 & 7.5 & 5.1 \\
\hline
\end{tabular}

Table 5. Loss of output (GVA) at end of 2021 under alternative policy assumptions

$\%$ change in output compared to 2019 level

\begin{tabular}{l|c|c|c}
\hline Borrowing ceiling (increase in borrowing as \% of turnover) & $\mathbf{0} \%$ & $\mathbf{5 \%}$ & $\mathbf{2 5 \%}$ \\
\hline "No Covid" Counterfactual & 3.0 & & \\
\hline Covid No Furlough (CJRS) & -2.5 & -1.7 & -0.7 \\
\hline Covid with Furlough (CJRS) & -0.6 & 0.3 & 0.9 \\
\hline
\end{tabular}

However, a fundamental question is whether policy could have been targeted more effectively, preserving output and rescuing firms that would have failed only as a result of the shock while not supporting firms that would have failed in any case. More effective targeting could reduce the fiscal costs and lower the chance of zombie firms surviving.

However, designing such a policy faces many challenges. The situation of firms is very diverse as Figure 2 shows, and $24 \%$ of the firms in the ORBIS sample begin with negative profitability. Overall, only $1.3 \%$ of profitable firms would have failed in normal times, while $6 \%$ of profitable firms would fail with the Covid-19 shock in the absence of policy (Table 6). This suggests a strong case for supporting profitable firms. However, looking at unprofitable firms, only $20 \%$ of them fail with the policy support, while nearly $40 \%$ would have been expected to fail in the counterfactual. A policy of targeting only profitable firms would nevertheless have led to the failure of around $20 \%$ of unprofitable firms (amounting to $5 \%$ of all firms), that would have survived without the Covid-19 shock. Profitability may also fluctuate from year-to-year, which complicates targeting this variable. ${ }^{15}$

Another approach would have been to target firms by sector. Among profitable firms, in those sectors most affected by the Covid-19 shock, the firms that would have failed without policy support would have overwhelmingly survived in normal times. With no policy support, $15 \%$ of profitable firms in Accommodation and Food Services would have failed, and almost $10 \%$ in both Wholesale and Retail, and Manufacturing (Table 6). By contrast, in the "no Covid" counterfactual only 1-3\% of these firms might have been expected to fail. There is a weak correlation across sectors of firm failures in normal times and under the Covid-19 shock, pointing to significant differences between the balance of intrinsic firm weakness and vulnerability to the Covid-19 shock across sectors.

\footnotetext{
${ }^{15}$ As noted above, this analysis subject to the caveats around the measurement of firms and their profitability in the ORBIS data.
} 
Table 6. The impact of support on firm survival by sector and initial financial health

\begin{tabular}{l|c|c|c|c|c|c}
\hline & \multicolumn{2}{|c|}{ Proportion of profitable firms who fail } & \multicolumn{3}{c}{ Proportion of unprofitable firms who fail } \\
\hline & $\begin{array}{c}\text { No Shock } \\
\text { Counterfactual }\end{array}$ & $\begin{array}{c}\text { Covid No } \\
\text { Policy }\end{array}$ & $\begin{array}{c}\text { Covid Both } \\
\text { Policies }\end{array}$ & $\begin{array}{c}\text { No Shock } \\
\text { Counterfactual }\end{array}$ & $\begin{array}{c}\text { Covid No } \\
\text { Policy }\end{array}$ & $\begin{array}{c}\text { Covid Both } \\
\text { Policies }\end{array}$ \\
\hline $\begin{array}{l}\text { Accommodation And Food } \\
\text { Service Activities }\end{array}$ & 1.7 & 14.9 & 1.2 & 40.8 & 55.9 & 20.7 \\
\hline $\begin{array}{l}\text { Arts, Entertainment And } \\
\text { Recreation }\end{array}$ & 0.7 & 4.3 & 0.4 & 13.0 & 25.7 & 4.2 \\
\hline Business Activities & 1.7 & 4.6 & 0.4 & 49.4 & 52.2 & 27.5 \\
\hline Construction & 0.6 & 1.9 & 0.2 & 49.2 & 54.8 & 24.6 \\
\hline Energy \& Water & 0.0 & 0.0 & 0.0 & 27.3 & 45.5 & 0.0 \\
\hline $\begin{array}{l}\text { Human Health And Social } \\
\text { Work Activities }\end{array}$ & 0.7 & 2.0 & 0.0 & 22.3 & 27.0 & 11.4 \\
\hline $\begin{array}{l}\text { Information } \\
\text { Communication }\end{array}$ & 1.4 & 4.8 & 0.4 & 22.8 & 23.7 & 11.0 \\
\hline Manufacturing & 2.5 & 9.6 & 0.0 & 45.1 & 50.7 & 16.4 \\
\hline Real Estate Activities & 0.0 & 1.2 & 0.0 & 83.3 & 83.3 & 25.0 \\
\hline Transportation And Storage & 0.7 & 8.0 & 0.7 & 32.4 & 37.1 & 22.9 \\
\hline Wholesale \& Retail & 1.3 & 9.9 & 0.7 & 29.1 & 44.0 & 8.1 \\
\hline Total & 1.3 & 6.0 & 0.4 & 37.9 & 43.5 & 18.7 \\
\hline
\end{tabular}

Source: Authors' calculations based on CAB model.

A significant limitation on policy targeting is that allowing unprofitable firms to fail could have negative externalities through the disruption of customer and supplier relationships, employment losses and trade credit. Unreported simulations suggest that a policy that would only support profitable firms would have led to lower output and the failure of some firms that would have supported with policy. While there are some negative externalities on suppliers firms and workers of these firm failures, the main reason for this worse outcome is that overall supports are less generous in this case. However, it is difficult for policymakers to assess the externalities. One practical implication, for example, is that it may be useful to have policies that support upstream suppliers as well as customer facing sectors. It also underlines the value of developing better statistics and improved understanding of the interrelationships between firms and how firms react in times of crisis.

Table 7. Experiment: The impact of stopping policy support in March 2021

\begin{tabular}{l|c|c|c}
\hline & \multicolumn{3}{|c}{ The impact of ending support } \\
\hline CJRS & Stop Both & Stop CJRS & Stop Borrowing \\
\hline Credit (\% of turnover) & Ends Mar 21 & Ends Mar 21 & CJRS maintained \\
\hline \% of firms failing by Dec 2021 & Ends Mar 21 & Maintained at 25\% & Ends Mar 21 \\
\hline Output in Dec 2021 compared to pre-crisis & 10.3 & 5.3 & 8.3 \\
\hline
\end{tabular}

Source: Authors' calculations based on CAB model.

One question facing policymakers is how to withdraw policy support. Table 4 shows the outcome of ending either or both policies in March 2021 as a policy experiment (the CJRS is due to be phased out gradually until September 2021 and there are numerous ongoing financial support packages). However, the exercise gives an insight into how robust the economy might be during spring 2021. If both policies were stopped, ${ }^{16}$

${ }^{16}$ Ending policy means stopping additional borrowing rather than repaying existing loans. 
overall failures would jump but remain overall close to the "no shock" level of $10 \%$ by the end of 2021 (Table 7). There would be a cost in terms of output with output falling nearly $2 p p$ below where it might be had policies persisted. This suggests that stopping the CJRS before the lending would have least detrimental impact because by April the use of the CJRS it past the peak. However, many firms remain reliant on ongoing credit: if the CJRS were maintained but lending ceases, there would be $8.3 \%$ failures by end December 2021, 3 percentage points higher than if both policies were kept in place. On the other hand, many of these firms may be among weaker firms with poorer prospects if they survive.

\section{Conclusion}

Covid-19 has led to an unprecedented shock to activity and firms' balance sheets. Applying the Corporate Sector Agent-Based (CAB) Model (Hillman, Barnes, Wharf and MacDonald, 2021) yields a number of insights on the complexity of how the shock has propagated through customer-supplier networks, taking into account the heterogeneity of firms' positions, their behaviour and interactions. The outcomes for individual firms depend on many factors, while the aggregate outcome turns on how firms interact and behaviour across the distribution of firms.

First, in the absence of any policy response, the COVID-19 shock would have led to a large peak fall in output and a persistent loss of output even if exogenous final demand recovered fully. Over $15 \%$ of firms would have failed in the first two years. Second, the massive policy response has been highly effective in supporting output and avoiding firm failure due to Covid-19. As has been observed in the bankruptcy statistics to date, the rate of firm failures is lower than in normal times. This counterintuitive outcome reflects in part that policy support helps weaker firms that would otherwise have failed, while protecting many firms that would have failed as result of the Covid-19 shock. Third, targeting policy on profitability or sectors may have helped to increase the efficiency of the policies, but may cause some firms to fail that would otherwise have survived and would have negatively affected otherwise viable firms. Looking at the role of different policy instruments, both the CJRS and credit guarantee supported activity, essentially by protecting workers' incomes and maintaining capacity. The availability of credit, however, appears to play a more powerful role in avoiding firm failures.

These results depend, to an extent on the assumptions made in the calibration and design of the CAB model. This highlights a number of key areas for future empirical research to understand better key features of the economy. First, improved understanding of firms' ability to borrow during normal and bad times is key to determining usual rates of firm failure and the outcome of large negative shocks. Second, increased knowledge of firm failure and the determinants of the decision to cease trading would help to improve the modelling of firm exit. Third, the formation of expectations plays a key role in the dynamics of the model and likely also underpin firms' ability to borrow and their decision to continue operations. However, adequate data to understand these decisions is lacking, and a key question is how firms and creditors view the future following the Covid-19 shock. 


\section{Bibliography}

Acemoglu,. D et al. (2012), "The Network Origins of Aggregate Fluctuations", Econometrica, Volume80, Issue. 5, September 2012, Pages 1977-2016.

Alix Partners (2021) "Market Recovery Monitor Review of GB Pub, Bar, and Restaurant Supply", May 2021, CGA-Alix Partners alixpartners-cga-market-recovery-monitor-may21.pdf

Bajgar, M., et al. (2020), "Coverage and representativeness of ORBIS data", OECD Science, Technology and Industry Working Papers, No. 2020/06, OECD Publishing, Paris, https://doi.org/10.1787/c7bdaa03-en

Bank of England (2020), "UK corporate sector financing and Covid-19" in Interim Financial Stability Report, May.

Baptista, R. et al. (2016), "Macroprudential Policy in an Agent-Based Model of the UK Housing Market", SSRN Electronic Journal, http://dx.doi.org/10.2139/ssrn.2850414

Bernard, et al. (2019), "The origins of firm heterogeneity: A production network approach", National Bank of Belgium Working Paper No. 362.

Bonaccorsi di Patti, E., et al. (2015), "The Role of Leverage in Firm Solvency: Evidence From Bank Loans", Italian Economic Journal, 1:253-286.

Chan-Lau, J. (2017), "ABBA: An Agent-Based Model of the Banking System”, IMF Working Papers, No. 17/136, International Monetary Fund.

Connell Garcia, W. and V. Ho (2021), "What Types of Firms Become Illiquid as a Result of COVID-19? A Firm-Level Perspective Using French Data", European Commission European Economy Dicussion Paper 136.

Demmou, L. et al (2021a), "Liquidity Shortfalls During the Covid-19 Outbreak: Assessment and Policy Responses, OECD Economics Working Paper, No. 1674.

Demmou, L. et al (2021b), "Insolvency and Debt Overhang Following the Covid-19 Outbreak: Assessment of Risks and Policy Response", I OECD Economics Working Paper, No. 1651.Fujiwara, Y. and Aoyama, H. (2010) Large-scale structure of a nation-wide production network. The European Physical Journal B. 77. 565-580

Gal, P. (2013), "Measuring Total Factor Productivity at the Firm Level using OECD-ORBIS", OECD Economics Department Working Papers, No. 1049.

Gourinchas, P. et al. (2020), "COVID-19 and SME failures", NBER Working Paper Series, No. 27887, National Bureau of Economic Research, Cambridge, MA, https://www.nber.org/system/files/working papers/w27877/w27877.pdf

Henriet, F. et al (2012), "Firm-network characteristics and economic robustness to natural disasters", Journal of Economic Dynamics and Control, 36(2012)150-167.

Hillman, R. et al. (2021). "A new firm-level model of corporate sector interactions and fragility: the Corporate Agent-Based (CAB) Model”, OECD Economics Department Working Papers, No. 1675.

Insolvency Service (2021) "Monthly Insolvency Statistics", April 2021. https://www.gov.uk/government/statistics/monthly-insolvency-statistics-april-2021/commentarymonthly-insolvency-statistics-april-2021

Jacobsen, T. and E. von Schedvin (2015), "Trade Credit and the Propagation of Corporate Failure: An Empirical Analysis", Econometrica, Vol. 83, No. 4 (July 2015), pp. 1315-137.

Lanz, R. and S. Miroudot (2011), "Intra-Firm Trade: Patterns, Determinants and Policy Implications", OECD Trade Policy Papers, No. 114, OECD Publishing, Paris, https://dx.doi.org/10.1787/5kg9p39/rwnn-en.

Leontief, W. (1986), "Input-Output Economics", 2nd ed., New York: Oxford University Press. 
Long, J. and C.. Plosser, (1983) Real Business Cycles, The Journal of Political Economy, Vol. 91, No. 1, pp. 39-69 Published by: The University of Chicago Press Stable URL: http://www.jstor.org/stable/1840430

Lucas, J. (1972), Lucas, R. E., Jr. (1972). "Expectations and the Neutrality of Money". Journal of Economic Theory. 4 (2): 103-124

McMahon, M. (2014), "Inventories in Motion: A New Approach To Inventories Over The Business Cycle", mimeo.

Plimmer, G (2018) "Carillion used suppliers as a lines of credit, says MPs", Financial Times, May 13th 2018 https://www.ft.com/content/a94f47cc-56ad-11e8-bdb7-f6677d2e1ce8

OECD (2017), Debate the Issues: Complexity and policy making, OECD Insights, OECD Publishing, Paris, http://dx.doi.org/10.1787/9789264271531-en

OECD (2020a), "Corporate Sector Vulnerability During The COVID-19 Outbreak", OECD Responses to Coronavirus COVID-19, May

OECD (2020b), "Evaluating the initial impact of COVID-19 containment measures on economic activity", OECD Responses to Coronavirus COVID-19, April

Pichler, A, M Pangallo, R M del Rio-Chanona, F Lafond and J D Farmer (2020), "Production networks and epidemic spreading: How to restart the UK economy", Covid Economics 23.

Pinto Ribeiro, S., S. Menghinello and K. De Backer (2010), "The OECD ORBIS Database: Responding to the Need for Firm-Level Micro-Data in the OECD", OECD Statistics Working Papers, No. 2010/01, OECD Publishing, Paris, https://doi.org/10.1787/5kmhds8mzj8w-en.

Sharma, D. et al. (2020), "V-, U-, L-, or W-shaped recovery after COVID: Insights from an Agent Based Model", SSRN Electronic Journal, http://arxiv.org/abs/2006.08469

Tian, C. (2018), "Firm-level entry and exit dynamics over the business cycles" 